\title{
Skogler: Photography at the Service of Falangism (Zaragoza, July 1936)
}

\author{
Diego Navarro-Bonilla \\ Department of Library and Information Science, Universidad \\ Carlos III de Madrid, Getafe (Madrid), Spain \\ dnavarro@bib.ucзm.es \\ Jesús Robledano-Arillo \\ Department of Library and Information Science, Universidad \\ Carlos III de Madrid, Getafe (Madrid), Spain \\ jroble@bib.ucзm.es
}

\begin{abstract}
This article analyses the role of 'Skogler' (Ángel Cortés Gracia), a photographer who worked for the insurgent Falangist forces in the city of Zaragoza, the capital of Aragón, from the beginning of the Spanish Civil War. Skogler's strong and early ties to the fascist movement, going back years before the war, suggest a special profile of an individual who supported the Falangist party by means of visual propaganda and printed photographs. Most of the photographs selected for study here have never been published before. They were shot in the early days of the military uprising against the Republic and help give us a more accurate understanding of armed fascism in the Aragonese capital, which ultimately fell to the rebels. This paper is part of an ongoing research project and exhibition to analyse and describe the contents and physical characteristics of the Skogler Archive, composed of more than 3,500 negatives recovered in diverse chronological phases.
\end{abstract}

\section{Keywords}

Spain - Spanish Civil War - Zaragoza - fascism - press photography - Spanish Falange - Skogler (Ángel Cortés Gracia), 1898-1986 - Fototeca de Huesca 


\section{The Skogler Archive as a Resource for Understanding the Visual Culture of Spanish Fascism}

Because of its historical significance and prominence in international press coverage from the earliest days of the rebellion, Spanish Civil War photography represents an essential chapter in the photographic record of the conflicts of the first half of the twentieth century. Contemplated from multiple points of view, angles and political orientations, over the past twenty years, the war has been scrutinised with an extremely high level of attention and detail that continues to turn up significant surprises. This is particularly true when, as in the cases analysed here, the photographic archive in question comes from the victors and, more specifically, from a member of the Falangist forces that rose up against the Spanish Republic. This is true of the Skogler photographic archive, which was located and recovered as a result of a meticulous search for documentary materials of very diverse origins and types dating from the 193 os to the late 1970s. This research draws on other recovery efforts involving the work of Falangist photographers as a result of searches in family archives, ${ }^{1}$ flea markets and auctions, like the one recently pursued by Javier Monjas for the legendary notebook of photographer Antonio Calvache, which contains his photos and personal remarks after observing the effects of the bombing of Guernica. ${ }^{2}$ Others have focused on the role played by Carlist soldiers. ${ }^{3}$ This article also aims to recover the identities and work of photographers aligned with the Falangist groups who would tried to 'develop an avant-garde aesthetic in the context of the fascist movements of Southern Europe', in the words of Ortiz-Echagüe. ${ }^{4}$

Not surprisingly, the prominent attention, both quantitative and qualitative, devoted to photojournalists with a vision sympathetic to the interests of

1 María Rosón Villena, 'El álbum fotográfico del falangista: Género y memoria en la posguerra española,' Revista de Dialectología y Tradiciones Populares 68 (2013); 215-238, https://doi. org/10.3989/rdtp.2013.01.010.

2 Borja Hermoso, "El "Guernica" que apareció en el Rastro: Un coleccionista halla el cuaderno donde el fotógrafo y falangista Antonio Calvache evoca el horror del bombardeo,' EL País, 21 May 2017; Juan Miguel Sánchez Vigil (exhibit curator), A. Calvache (1896-1984) [exhibit catalogue] (Madrid: Centro Cultural del Conde Duque, 1994).

3 Pablo Larraz Andía and Víctor Sierra-Sesúmaga, La cámara en el macuto: Fotógrafos y combatientes en la Guerra Civil Española (Madrid: La Esfera de los libros, 2018).

4 Javier Ortiz-Echagüe, 'José Compte: De la fotografía publicitaria a la propaganda en la guerra civil española (1936-1939),' Comunicação Pública 12, no. 23 (2017), https://doi.org/10.400o/ cp.1972; Aleix Purcet Gregori and Juan Alonso Fernández, 'Fascismo, Guerra y Fotografía: La Mirada de la Nueva España,' Girona 2014: Archivos e industrias culturales, https://www.girona. cat/web/ica2014/ponents/textos/id22.pdf, accessed February 2019. 
the Republic generates a problem of partial focus not altogether free of bias in terms of the visual discourse about the conflict. ${ }^{5}$ Research on Spanish Civil War photography, spurred in large part by what is known as the 'recovery of historical memory', requires a comprehensive approach in which photographers of the legendary stature of Capa, Taro, Centelles, Boix, Horna, Deschamps, Joaquín Sanchís 'Finezas', Alfonso, Santos Yubero, Campúa and others are being augmented by recognition of those who recorded the conflict from the comfort of their position on the winning side; those who started out as rebels and ended up as victors. ${ }^{6}$ The work of a documentary nature presented here aims to contribute, by means of a systematic examination of the gaze of a Falangist photographer, to the visual narration of 'his war', from his partisan perspective, not the war of the victors in the abstract but that of the original Falangists, the Camisas Viejas [Old Shirts] or the Vieja Guardia [Old Guard].

In short, it aims to highlight the contribution of the history of Civil War photography to what Michel Lefebvre called 'the drama of Spain', in which 'the battles of memory result in a lack of consensus on how to tell the story of the war.' Discoveries like the 'Skogler' archive confirm photography's significance as a primary source for enhancing the photographic history of the Spanish conflict at the service of one of the most important forces on the rebel side: the Spanish Falange movement founded by José Antonio Primo de Rivera in $1933 .{ }^{8}$

Photography would quickly assume the capacity of the propaganda apparatus as an essential instrument, as Ortiz-Echagüe, Purcet and Alonso have rightly pointed out, and would serve not only to consolidate the visual communication strategy of an ideology of radical social transformation but also to enforce the visibility of the Spanish Falange as the only, although initially small, fascist party in Spain prior to the outbreak of the Civil War.

The main photographs on which this paper is based are part of a series of over 3,500 silver gelatin negatives on a plastic base, in 6xy-cm format mainly, shot during the Civil War and in the postwar period. They are perfectly conserved

5 Víctor Mora and Beatriz de las Heras, 'Retratando el Madrid de la Guerra Civil: Santos Yubero in the Archivo Regional de la Comunidad de Madrid', Revista General de Información y Documentación 24 (2015): 343-371; Beatriz de las Heras Herrero, Imágenes de una ciudad sitiada: Madrid 1936-1939: Colección inédita de fotografías de la Guerra Civil (Madrid: JC, 2009).

6 A status and much more complete and essential synthesis of the matter at hand is provided in Juan Miguel Sánchez Vigil, La fotografía en España: Otra vuelta de tuerca (Gijón: Trea, 2013), 267-282.

7 Michel Lefebvre-Peña, España 1936-1939: Guerra gráfica: Fotógrafos, artistas y escritores en guerra (Barcelona: Lunwerg, 2013), 15.

8 Antón Castro, 'Huesca rescata el Archivo Skogler,' Heraldo de Aragón, 6 November 2010, http:// www.heraldo.es/noticias/cultura/huesca_rescata_archivo_skogler.html, accessed February 26, 2019 . 
today in the Fototeca de Huesca. Their condition is acceptable, although many of their photographs reveal problems of fragility, reductive oxide deterioration and loss of density in the final image. The study of the physical characteristics and digitisation operations for conservation purposes are part of an extensive and ongoing research project, and exhibition. ${ }^{9}$

The extraordinary value of this photographic archive for documenting numerous aspects of the civil conflict as a whole is heightened when photographs are identified that show the armed mobilisation of the Falange of Zaragoza in the first days of the military uprising. Detailed study of these images shot around Monday, 20 July 1936 (just two days after the 'military pronouncement' in all of Spain) unequivocally situates the fascist forces, whose participation proved crucial to the rebels' victory, in the Aragonese capital at a particular point in time and in a particular city. To the best of our knowledge, never before has such precise photographic coverage of Falangist participation in the occupation of Zaragoza been available from within the organisation itself, with the nerve centre of the armed Falangists located in the Torrero or Castillejos barracks as the reference point.

On the other hand, from a medium-sized city, Zaragoza, that was nonetheless fundamental in the pro-Franco forces' overall defensive apparatus, Skogler would attempt to transcend the strictly local or regional dimension of the Falange's activity. In fact, he would record numerous instances of fraternisation with the main international inspirations of Spanish fascism. Not surprisingly, the representatives in Zaragoza of the Italian Fascio, the delegates of the German National Socialist Party in the city, and the solemn visits of different German delegations, such as that of the Hitlerjugend in November 1937, suggest an attempt to break out of the strictly provincial dimension of coverage of local or regional action by the city's fascist forces (see figures 1 and 2).

\section{Photography and Civil War: The Specific Case of Aragon}

Very noteworthy syntheses, like those of Carmelo Tartón Vinuesa, ${ }^{10}$ and research projects, like those undertaken by Paola Barrau Azara, or by Cristina Martínez de Vega, based on the photographic archive of her grandfather,

9 The exhibition 'Skogler: El visor falangista de la Guerra Civil y la posguerra' at the Fototeca of Huesca will run from 28 May to 1 August 2021, https://www. dphuesca.es/oferta-cultural/exposiciones/-/asset_publisher/4KJPco8Ivizp/content/ skogler-el-visor-falangista-de-la-guerra-civil-y-la-posguerra/maximized.

10 Carmelo Tartón Vinuesa, Los fotógrafos aragoneses (Zaragoza: CAI, 1999). 


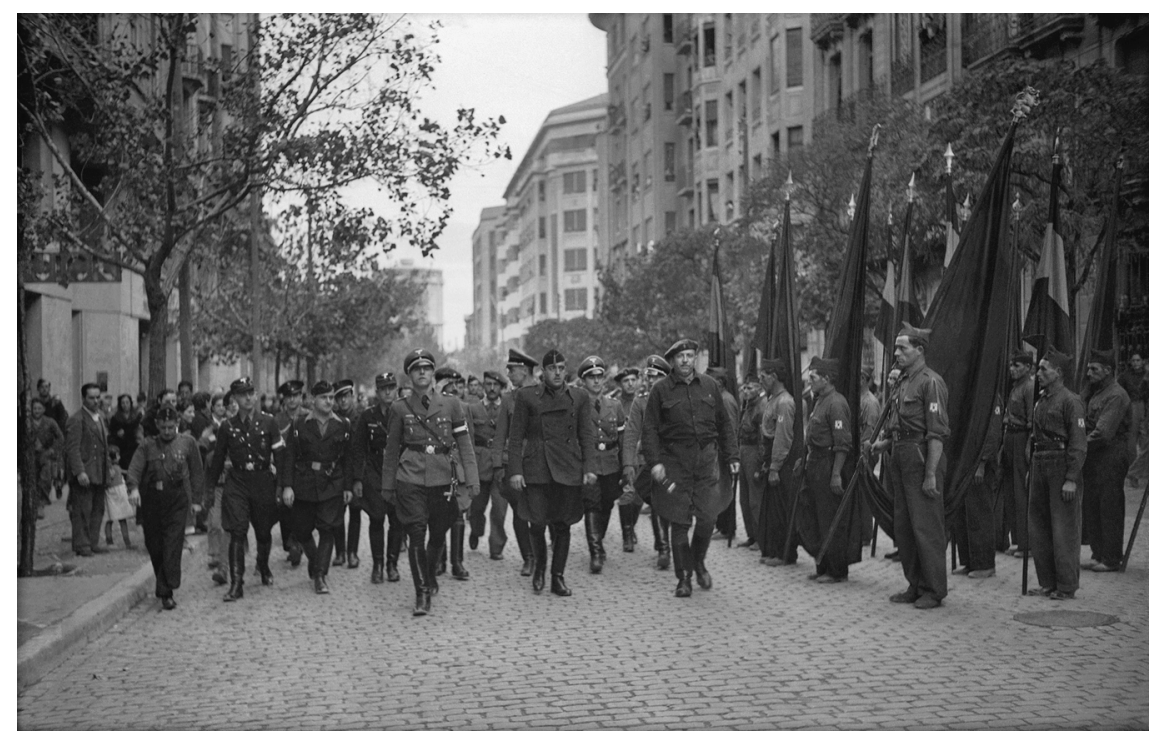

FIGURE 1 Official visit of the Hitlerjugend delegation to Zaragoza. Falange chief Jesús Muro and other fascist leaders take them to the military parade, 9 November 1937. SOURCE: FOTOTECA DE HUESCA, SKOGLER ARCHIVE, NO. 2493.

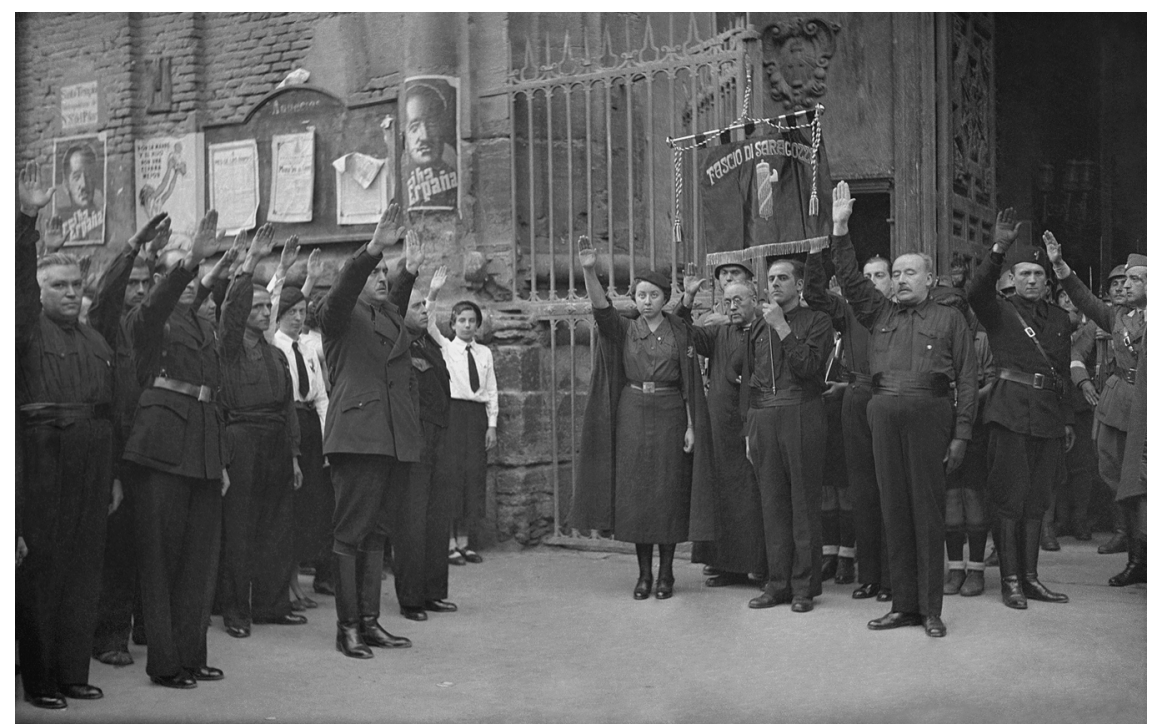

FIGURE 2 The Italian consul, Falangist chief Muro and Italian Fascist party members near the main entrance of the Basílica del Pilar cathedral, Zaragoza, 2 November 1937. SOURCE: FOTOTECA DE HUESCA, SKOGLER ARCHIVE, NO. 2655. 
'Kautela,'11 under the direction of professor María del Carmen Agustín Lacruz, reveal the interest in photography generated in Aragon during the Civil War. ${ }^{12}$ From Capa to Sandri and Francone, from Horna to Centelles, Spanish and international photographers alike who visited the fronts of Aragón documented both the action behind the lines and the most intense combat from their political positions and beliefs. These are disparate depictions, like those of the Falangist Antonio Cobos in his special combat diary and those in the José María Lahoz archive, or the photos taken by the Australian nurse Agnes Hodgson, among others, that were brought together in the photography exhibit Aragón en Guerra. Perfiles ['Aragón at War: Profiles'] curated by Víctor Pardo Lancina. ${ }^{13}$ The studies and exhibits related to all of them offer quite a few visual resources that complement and can be usefully compared to the archive analysed here. Likewise, the ongoing contributions of historians and scholars of the Civil War period in Aragón have spurred interesting exhumations of photographic archives focused on this wartime Aragón, with projects like those coordinated by Fernando Martínez de Baños Carrillo or Francisco Escribano Bernal, based on photographs from very diverse and, for the most part private, archives such as the Campos Family Archive, the Allánegui Archive, those of José María Lahoz and Jaime Cinca Yago, the Juan Guzmán Archive and the Pedro González Archive. ${ }^{14}$

Nonetheless, the list of journalists and photography professionals on both sides who covered the conflict from the fronts of Aragón is extensive. Institutions like the Fototeca de Huesca are reference centres in the conservation and dissemination of the rich photographic heritage in this Spanish Autonomous Community, ${ }^{15}$ and they join projects with enormous impact such as 'Amarga Memoria' ['Bitter Memory'], coordinated by the Department of Education, Culture and Sport of the Community of Aragon. ${ }^{16}$ To this, we

11 Cristina Martínez de Vega, 'Francisco Martínez Gascón: Análisis documental de su producción fotográfica, 1930-1945' (PhD diss., Universidad de Zaragoza, 2016). Cristina Martínez de Vega, Víctor Lahuerta, Kautela: Un fotógrafo en la España franquista (1928-1944) (Zaragoza: Institución Fernando el Católico, 2018).

12 Paola Barrau Azara, 'Fotografías de la Guerra Civil en Aragón: El fondo Antonio Cobos Berges' (PhD diss., Universidad de Zaragoza, 2015).

13 Víctor Pardo Lancina, Aragón en Guerra: Perfiles [exhibition catalog] (Huesca: Gobierno de Aragón, 2006).

14 Fernando Martínez de Baños Carrillo, Guerra Civil: Aragón (Zaragoza: Delsan, 2010). Francisco Escribano Bernal, Guerra Civil: Aragón II: Imágenes (Zaragoza: Delsan, 2005).

15 Vid, Orwell toma café en Huesca (Huesca: Gobierno de Aragón; Ayuntamiento; Diputación Provincial, 2017).

16 The group of exhibits and works sponsored by this program have been recognised for their quality and originality in the recovery of practically unknown documentary and 
must add the noteworthy efforts to recover and definitively conserve first-rate legacies such as the archives of Coyne Jalón Ángel, Jarke, and others. Likewise, in-depth research on photographic pioneers in the Aragonese capital during the final years of the nineteenth century and earliest years of the twentieth century, like that of Javier Turrión on Gustavo Freudenthal, should be considered benchmarks. ${ }^{17}$

\section{Fotografía Skogler: The Trade Name of Ángel Cortés Gracia and his Fascist Commitment}

In the photographic landscape of Civil War-era Zaragoza, the outstanding figure of Jalón Ángel seems to have eclipsed other names in the research on contemporary photographic history. As a result, Ángel Cortés Gracia (1898-1986) - better known by his professional name 'Skogler' - has been underrated in the historiography, which this paper seeks to rectify. ${ }^{18}$

The 'Fotografía Austríaca' and 'Fotografía Skogler' establishments and commercial names were already a professional brand prior to them becoming synonymous with Ángel Cortés Gracia who adopted the professional name 'Skogler' in the 193os. Therefore, the negatives that form the basis of this project were not the work of Carlos Skogler Frediksson, the original owner of the studio, but of Ángel Cortés/Skogler who managed the studio in the 1920s. To properly appreciate Ángel Cortés' contribution to the Falangist movement in the Aragonese capital, of which he was an original founder, thereby acquiring the status colloquially known as Camisa Vieja [Old Shirt] or elite member of the Vieja Guardia [Old Guard], we have to go back to the 193os. Ángel Cortés would become a prominent figure in the foundational moment of the Spanish Falange in Zaragoza, and he would synergistically combine his profession as a photographer with his political strong militancy. ${ }^{19}$ Romero Santamaría traces this militancy to Ángel Cortés' marriage to Teresa Sanz Riera, an active member of the Sección Femenina del FET y de las JONS (the women's branch of the Falange political movement) and a close friend of its founder, Pilar Primo de Rivera. ${ }^{20}$

photographic archives. See, for example, the book on Italian photographer Michele Francone, Francone: La mirada de Mussolini en la guerra de España (Huesca: Gobierno de Aragón; Alcañiz: Ayuntamiento, 20o9).

17 Javier Turrión Berges, Gustavo Freudenthal Cónsul de Alemania en Zaragoza: Fotógrafo de la Real Casa (Zaragoza: Ediciones Vetera, 2012).

18 Gregori and Fernández, 'Fascismo, Guerra y Fotografía.'

19 The formation of the Falange in Zaragoza in the mid-thirties is covered by diverse works, such as that of Ángela Cenarro Lagunas, Cruzados y camisas azules: Los orígenes del franquismo en Aragón, 1936-1945 (Prensas Universitarias de Zaragoza, 1997).

20 Alfredo Romero Santamaría, 'Fotografía industrial, artística y de guerra en Zaragoza (19231943),' in Fotografía de la Guerra Civil en Zaragoza: Los talleres Mercier, fábrica de municiones (1936-1939) (Zaragoza: Diputación Provincial, 2010), 53-93. 
The founding document, on 26 February 1933, of the group called Al Servicio de España [At the Service of Spain] is considered the first official record of the origins of the FET in Zaragoza. This organisation brought together members of Primo de Rivera's Patriotic Union and Dr Albiñana's Spanish Nationalist Party, university students who were followers of Ramiro Ledesma, and retired soldiers residing in Zaragoza. ${ }^{21}$ Its first chairman was Jesús Muro Sevilla, with Ángel Cortés Gracia and Mariano Blasco as vice-chairmen. This primitive Falange of Zaragoza would become consolidated after the historic rally of 29 October 1933, the foundational moment of the Falange of José Antonio Primo de Rivera.

The year 1933 was pivotal for Ángel Cortés, as his intense political activity within the circles of the primitive Falange of Zaragoza coincided with Carlos Skogler's move to Pamplona. He left his photography studio in the hands of his main assistant, Cortés, who maintained the business name. ${ }^{22}$ That link to the embryonic Falange of Zaragoza was brutally revealed on 23 July 1933, when the Assault Guards proceeded to violently close the premises of Acción Popular and the Al Servicio de España group. In parallel, many of the leaders of the latter, among which the newspapers of the day identified Pablo Navarro Lambán (treasurer), Vicente Vila Navarro (general secretary), Ángel Cortés Gracia (first vice-chair), were arrested.

The networks of family ties and social support of the emerging Falangist movement are manifested in the Cortés-Sanz circle in revealing ways. ${ }^{23}$ Based on the studies by Eduardo González Calleja, ${ }^{24}$ F. Sevillano Calero ${ }^{25}$ and, in particular for Zaragoza, Ángel Alcalde, it is possible to distinguish two groups of adherents, enthusiastic and passive, that provide a sufficient, cohesive and militant social base to consolidate their power: 'while violence was strongly connected to the realisation of fascism and was the primordial ferment that gave rise to the submission and passivity of the population, conquest of the masses by fascism also needed the support of another series of cultural or propagandistic instruments.' ${ }^{26}$ In short, through the documentary testimonies

\footnotetext{
21 Ángela Cenarro Lagunas, Cruzados y camisas azules.

22 Alfredo Romero Santamaría, 'Fotógrafos en la prensa aragonesa,' Artigrama, no. 27 (2012): 153-173.

23 Ángel Alcalde Fernández, Lazos de sangre: Los apoyos sociales a la sublevación militar en Zaragoza: La Junta Recaudatoria civil (1936-1939) (Zaragoza: IFC, 2010), 431-484.

24 Eduardo González Calleja, 'Los apoyos sociales de los movimientos y regímenes fascistas en la Europa de entreguerras: 75 años de debate científico', Hispania 61, no. 207 (2001): 17.

25 Francisco Sevillano Calero, 'Consenso y violencia en el Nuevo Estado franquista: Historia de las actitudes cotidianas,' Historia social 46 (2003): 159.

26 Ángel Alcalde Fernández, Lazos de sangre.
} 
and, especially, the presence of Ángel Cortés in the photographs of the Falange from the very beginning, in July and August 1936, in the activism around the Castillejos/Torrero barracks, we can understand this two-pronged influence, or the two faces of the Falange in Zaragoza: 'the purely violent and repressive face and, behind it, a persuasive, gentler one, whose forefront consisted of social policies designed to contain and control the population'.27 It is still premature to determine the degree of his participation in the former; what is not in question is that Ángel Cortés would go on to occupy an extremely prominent place in the latter, by disseminating ideas and propaganda through the powerful photographic medium he dominated.

As a professional, the main event that clearly determined his leading role as a photographer affiliated with the Falange of Zaragoza would be his prompt hiring by the newspaper Amanecer: Diario nacional sindicalista [Dawn: National Sindicalist Newspaper] immediately after its first issue on 11 August 1936. From that day to a few months after the end of the conflict, hundreds of photographs taken by Ángel Cortés Gracia, who always signed his work under the name Skogler, appeared in that daily newspaper. However, his photos would not only appear on the pages of this newspaper but he would also occasionally collaborate with other publications, clearly leaving his pro-Franco mark, despite not appearing in the official register of journalists. ${ }^{28}$ (Ángel Cortés applied for inclusion on several occasions but never received a reply from the National Press Office).

Therefore, Skogler was a working photographer long before the emergence of leading Falangist publications, such as Vértice or Fotos, titles largely studied by Aguilar and Martín, or the official creation of a national propaganda service. In a way, he was already exercising his nascent Falangism prior to the consolidation of guidelines from institutions, apparatuses and slogans that would later focus propaganda work under the direction of Dionisio Ridruejo or Giménez-Arnau, for example.

After the war, the voluminous Historia de la Cruzada Española [History of the Spanish Crusade] would also feature some Skogler images. ${ }^{29}$ Ángel Cortés did not neglect his photography studio, where he would continue producing 'civilian' photographs and others of a 'touristic-patriotic' nature, such as an undated series of patriotic postcards.

27 Ibid.

28 This official register included the names of all journalists up to 1 January 1967. It was consulted in the General Archive of the Administration (Alcalá de Henares).

29 Also reprinted in Historia de la Cruzada Española (Madrid: Ediciones Españolas, 1941) vol. 4, no. 14, 213 . 


\section{Objectives and Methods}

Analytical study of approximately 3,50o photographs that currently make up the Skogler collection ideally should not culminate with the basic technical tasks of cataloguing, describing, preserving and disseminating it to researchers. In general, we have made an effort to situate these images in space and time, and to provide more information to contextualise and expand our knowledge of the role the Falangist forces played in the occupation of the city immediately following the military uprising by a sector of the Spanish army. This occurred in the North African garrisons of Melilla, Tetuán, Larache and Ceuta on the night of 17 July 1936, and was made official the following day. The richness of the Skogler photographs raises a series of questions that guide the research and raise topics for discussion.

Therefore, this article proposes, first, to present the Skogler Archive to the scientific community of scholars and researchers in the field of Spanish fascism. The relevance of these materials makes them a valuable source for addressing multiple aspects captured in the photos. These range from the interaction between Spanish, German and Italian fascism to the intense propagandistic and social action of a Falangism whose presence in Zaragoza during the conflict was ubiquitous. For this reason, essential details about the photographer, the Falangist Ángel Cortés Gracia ('Skogler'), are provided based on initially confusing information. In fact, for decades it was said, without much objective evidence, that the name Skogler referred to a German photographer living in Zaragoza after the First World War. Our research, based on various documentary sources and the municipal census, in addition to access to the limited available bibliography that tangentially addresses the Skogler Archive, leads us to conclude that the photographer Ángel Cortés was indeed behind the Skogler commercial brand. This conclusion has been confirmed as a result of conversations with the descendants of the photographer himself, to whom we are profoundly grateful for all their clarifications. To better understand this photographer and his work, it is necessary to consider precisely how two facets are intertwined - that of a professional photographer, whose technique and quality are unquestionable, and that of an early and veteran Falangist militant and, therefore, a member of that elite class of members of the fascist party well before the start of the Civil War.

Second, we address this photographer's 'Falangist gaze' over the course of the conflict and occupation of the Aragonese capital by the rebel troops. To do so we consider the context of war photography and identifying affinities and contrasts with the work of other photographers who covered the same period and worked in the same city, a series of synergies that will no doubt generate 
subsequent comparative studies. To do so, a pre-selection of images from the photographic archive was proposed to make it possible to document the hectic first days of the military uprising in the Aragonese capital.

The relevance of the photographs selected for this article are based on two criteria: their unpublished status and their historical importance insofar as they bear witness to Falangist preparations precisely in the first days of the Spanish Civil War from inside the organisation itself. Indeed, these images are probably the only ones in existence in the context of the entire conflict, not only in Zaragoza but anywhere in the territory that took up arms against the Republic, and which record, from within and as early as 20 July 1936, the military preparations of the forces of the so-called 'national revolt'. The images have been studied in detail to contextualise each of them geographically and chronologically. Knowledge of the events at the beginning of the uprising in the Aragonese capital helped to pinpoint the epicentres of the rebellion. In each image, we have identified the most relevant locations, individuals and actions in those fateful days of July 1936, a series of actions that are directly connected to the course of events that would eventually lead to complete military control of the city by the rebel forces.

The method used was an iconographic analysis of buildings, individuals, armaments, and streets that still exist in the city of Zaragoza, among other aspects. In other words, an exhaustive photographic analysis by means of historical comparison. The formal analysis of these first images that bear urgent witness to events in July 1936 reveals a contrast with the photographs 'Skogler' would take of the conflict from August 1936 onwards. If in the first photos studied here, from July, there is the prevailing sense of immediacy of a person who is witnessing the Falangist participation in the uprising, in the second ones, now being dispatched daily to Amanecer, the fascist visual rhetoric is clearly defined in connection with Falangist political and aesthetic ideals.

The Castillejos/Torrero Cavalry Barracks of Zaragoza serve as an essential locus for the crucial participation of the fascist forces in connivance with the military units in rebellion against the Republic. This is the backdrop for Skogler's action of photographically recording, from within the Falangist epicentre, the uprising, the preparations and the orders for carrying out the military deployment in the city and towns in which the ferocious fascist repression was unleashed. This repression was led precisely by these same Falangist forces as both a vanguard and rearguard element. Skogler's subsequent photographic activity must also be explained as a result of his association with the Falangist newspaper Amanecer. Nonetheless, at that point (July 1936), these photographs are not propagandistic but purely testimonial, and that makes them more significant. In fact, the exceptional value of the images selected 
here is that they were not published in this newspaper, as this only started publication on 11 August 1936. Amanecer was initially headed by Maximiano García Venero and shortly thereafter by Ubaldo Pazos, the provincial chief of press and propaganda and director of the newspaper for practically the entire war. ${ }^{30}$ In figure 3 , we include two images that are representative of one of the newspaper's earliest moments (13 August 1936). The front page of the newspaper with the main headline of that day leaves no room for doubt regarding the fascist nature of its rhetoric.

\section{Research Questions}

To what extent did a professional photographer who had not stepped out of his circle of local activity contribute, from the perspective of his intense Falangist militancy, to consolidating the fascist propaganda apparatus long before the official propaganda structures of the rebels were established? How can the gaze of a markedly Falangist photographer be described? What technical principles did he apply to the act of recording the events which, unavoidably, were filtered through a very significant ideology in the political context of the nineteen thirties in Spain? What is undeniable about the study of the Skogler's photographs is that his professional activity contributed directly and effectively to the intense efforts to propagandise for the Falangist party, the Falangist ideology and the continuous presence of the Falange in Aragonese public life: 'Falange was once again appropriating ceremonies and tributes, which, in the name of Spain, it utilised for its own propagandistic and political ends.' ${ }^{31}$

The research discussed here will be guided by visual narration of the scenes, identification of the men and women portrayed and how some of these photographs were used in a daily dynamic of journalistic publication, as well as Skogler's interaction with the rest of the Falangist propaganda apparatus, including other photographers, such as Jalón Ángel, with whom relationships were not always easy.

30 José Antonio de las Heras Pedrosa, La prensa del movimiento y su gestión publicitaria, 19361984 (Málaga: Universidad de Málaga, 2000); Begoña Zalbidea, 'Prensa del Movimiento en España: 1936-1983' (PhD diss., Universidad del País Vasco, 1996).

31 Dimas Vaquero Peláez, Creer, obedecer, combatir... Y morir: Fascistas italianos en la guerra civil española (Zaragoza: IFC, 2006); Dimas Vaquero Peláez, Aragón con camisa negra: Las huellas de Mussolini (Zaragoza: Rolde de Estudios Aragoneses, 2011), 242. 

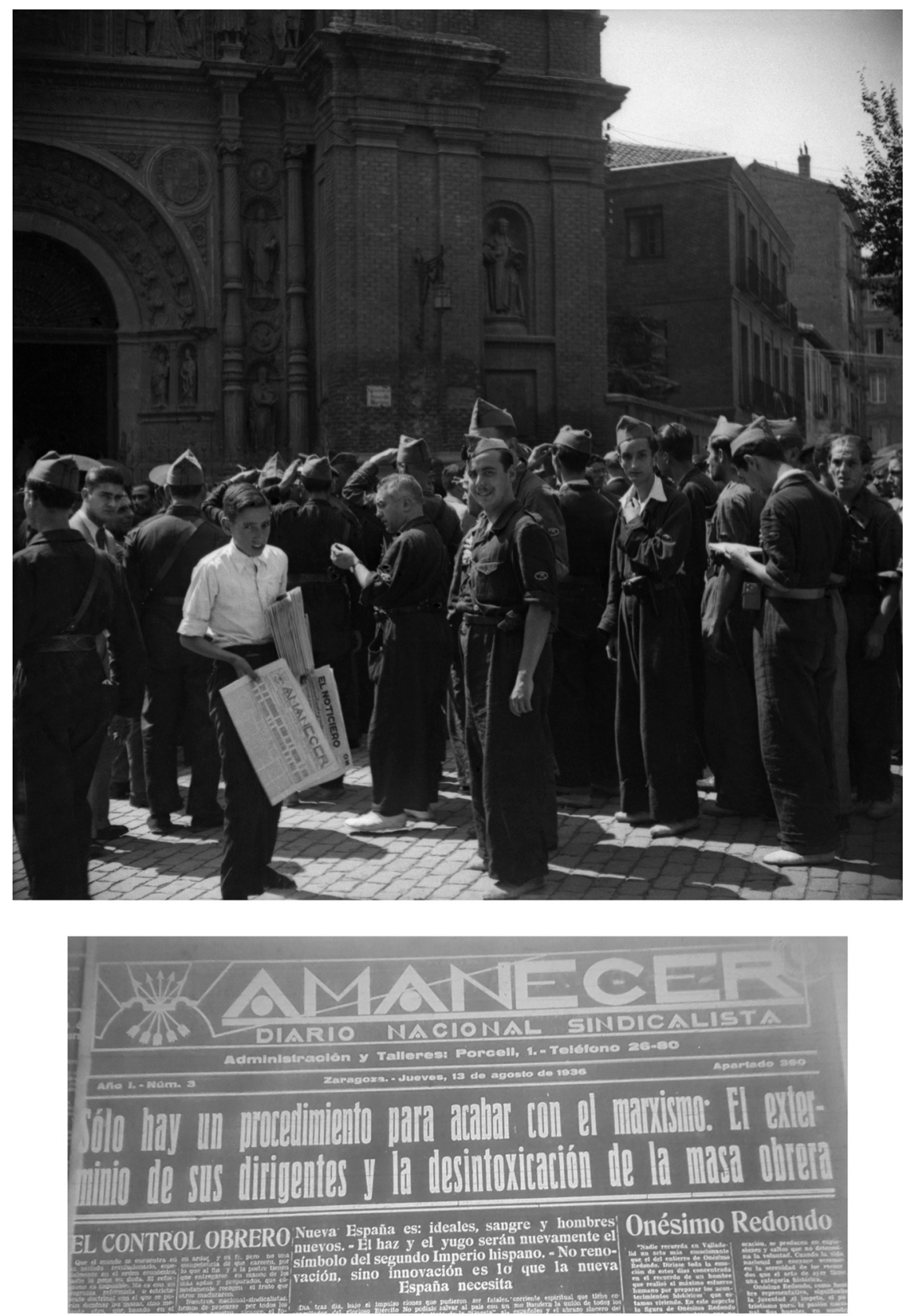

FIGURE 3 Above, distribution of copies of the newspaper Amanecer, Church of Santa Engracia, 13 August 1936. Source: Fototeca de Huesca, Skogler Archive, no. 87. Below, the front page of Amanecer that day.

SOURCE: ZARAGOZA, ARCHIVE-LIBRARY OF THE CITY HALL, MICROFILM. 


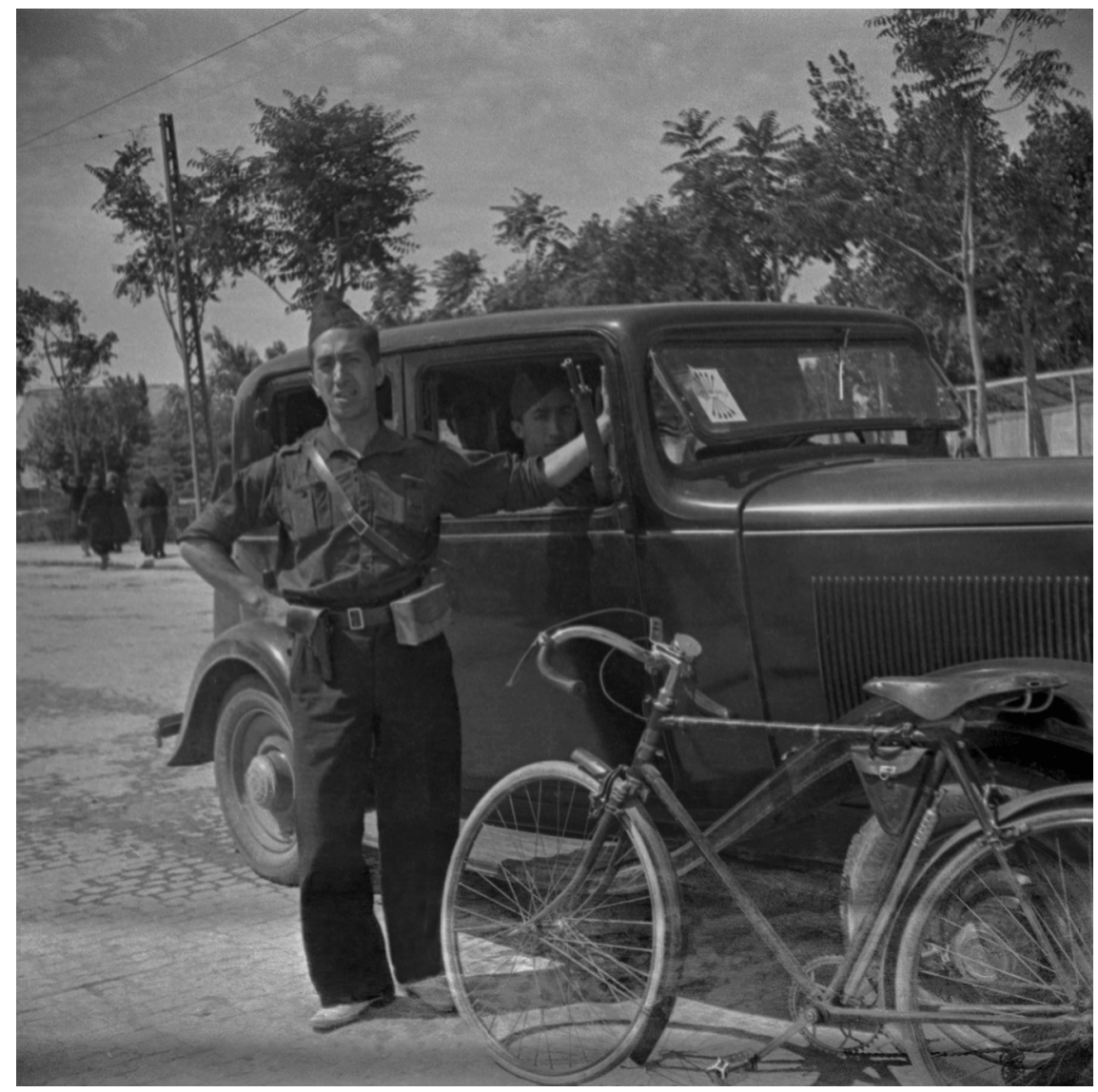

FIGURE 4 First moments of the uprising in Zaragoza. Ángel Cortés, alias Skogler, in the Falange field uniform, in the vicinity of the Torrero/Castillejos barracks [19-24 July] 1936).

SOURCE: FOTOTECA DE HUESCA, SKOGLER ARCHIVE, NO. 172.

\section{Results: The Gaze of a Falangist}

Unlike others, such as Compte, who 'had to change their profession or adapt their skills when the war broke out', 32 Skogler was a photographer with a firm commitment to Falangist ideology well before the start of the Civil War. He did not need to change anything or adapt his skills, because the interrelation between photography and the Falangist movement was the most natural thing in the world for him.

32 Ortiz-Echagüe, 'José Compte.'; Gregori and Fernández, 'Fascismo, Guerra y Fotografía.' 
If the main source for studying Compte's propaganda work was the elegant magazine Vertice, the main one for studying Skogler's was the newspaper Amanecer, on whose pages he would cover the entire conflict very actively. Postcards, official portraits and contributions to some other ephemeral lifestyle publications, such as Vida Aragonesa: revista ilustrada [Aragon Life: Illustrated Magazin], in addition to many other serialised publications from those years, are complementary sources for studying his photographic work. ${ }^{33}$ However, far from being a mere rearguard or local photographer, Skogler would also cover battlefronts, such as that of the Sierra de Madrid in the summer of 1936; Madrid again in November, where he was wounded by a projectile dropped on his car; the Northern Front; Teruel; and, finally, the first days of the conquest of Madrid and the Victory parade on a triumphal Paseo de la Castellana in May 1939.

In Skogler's photos, we see basically one Falange, that of official ceremonies, of continuous and ubiquitous representation among the group of forces that would lead to the final victory by the rebels. ${ }^{34}$ It is the socially active Falange, the force of the trade union revolution taking place, one that is focused on achieving victory but also concerned about social problems like housing, sanitation, supplying basic goods, and reforestation. It is a Falange that habitually occupies the urban centre of the city's public sphere, the images of which will open the door to subsequent studies on the geography of the repressive terror in the city of Zaragoza. But in the photographic negatives, another Falange shows its face, one that is less official, more internal and focused on comrades: the Falange of leather shoulder belts and armed squads, the one that Skogler, as an active member of same, the photographer-Falangist-Camisa Vieja, reflects in an act of self-representation. It is the Falange of the periphery of the Aragonese capital, the one that situates its centre of gravity outside the public spotlight of the official city centre, a more sinister one concentrated around the Castillejos or Torrero barracks, the site of the mass of the armed uprising in the city. In one set of negatives, small in number but very powerful visually, we can localise this activist Falange of men and women who go in and out of the barracks, vehicles that depart and return, in a summer that we can easily imagine: the hot and repressive one of 1936. The negatives serve to

33 Jordana Mendelson, Revistas y Guerra 1936 (Madrid: Museo Nacional Centro Arte Reina Sofía, 2007).

34 María del Carmen Agustín Lacruz, 'El contenido de las imágenes y su análisis en entornos documentales,' in Polisemias visuales: Aproximaciones a la alfabetización visual en la sociedad intercultural, ed. Raquel Gómez Díaz and María del Carmen Agustín Lacruz (Salamanca: Universidad de Salamanca, 2010), 85-116. 
define a symbolic space in the Torrero district that enables a discourse centred around the three vectors that coincided in that neighbourhood which, in 1936, was clearly on the outskirts of the city. They are the three C's that are, dramatically and in a sinister feedback loop, identified with the nearby Torrero Cárcel (prison), where Father Estella would document the deaths of so many victims of repression and gunshot wounds in his, today, essential testimony; the aforementioned Falange headquarters, called 'Castillejos' or Torrero; and, lastly, the Cemetery in the same neighbourhood, where the Falangists posed for photographs while burying comrades fallen in combat, accompanying each martyr with the full fascist ceremonial apparatus, a cemetery against whose walls firing squads shot people practically every night until well into the first year of the war.

Systematic study of Skogler's negatives shows a clear intention in his photographic work, that of fulfilling the propaganda objectives of the publication for which he works: the newspaper Amanecer, the organ of expression and propaganda of the Falange of Aragon. Thus, his photographs are not fascist in nature, per se, but more accurately Falangist, aimed at constant exaltation of the role played by a particular vision of the conflict. This has important social connotations and reflects the social fascist revolution described in articles about the construction of low-income housing, soup kitchens, etc.

With his camera, Skogler depicted a Zaragoza in wartime from behind the lines, one whose society was dominated by the structures of the rebel forces that took up arms against the legitimate government of the Republic and, very significantly, by the Falange of the Aragonese capital. Thus, the city, its streets and its different corners also become protagonists in an urban space appropriated to commemorate, celebrate, influence and reinforce patriotism, ideals or moralistic rectitude.

From the perspective of technique and innovation, Skogler was a very talented and formal photographer trained more in the style of classical early twentieth century photography than of the avant-garde of the twenties and thirties. Nonetheless, it is possible to find some interesting new resources and techniques clearly being applied to the public and propaganda photography. For instance, his ability to move quickly from one vantage point to another to shoot the same event from multiple perspectives is always surprising. Skogler's use of high and low angles, extreme bird's-eye views, eye-level shots, long shots, among others, are some of the types of techniques to underscore the monumentality of his depictions and the fascistic public staging of numerous paramilitary parades (see figures $5,6,7,8$ ).

It is common to find depictions of demonstrations of patriotic fervour and the daily public rallies for the most unlikely of celebrations as a subordinate 


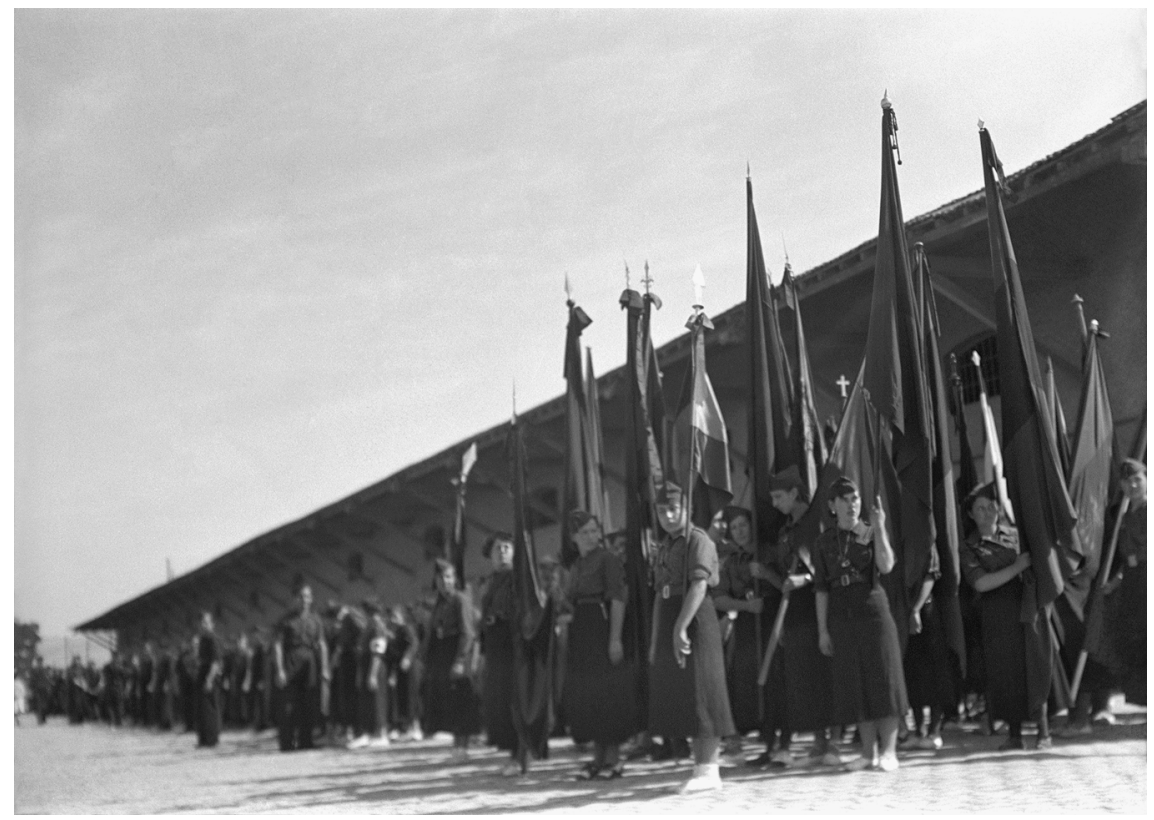

FIGURE 5 A column of Falangist women in formation displaying their flags in the city of Calatayud, 4 October 1936.

SOURCE: FOTOTECA DE HUESCA, SKOGLER ARCHIVE, NO. 3345.

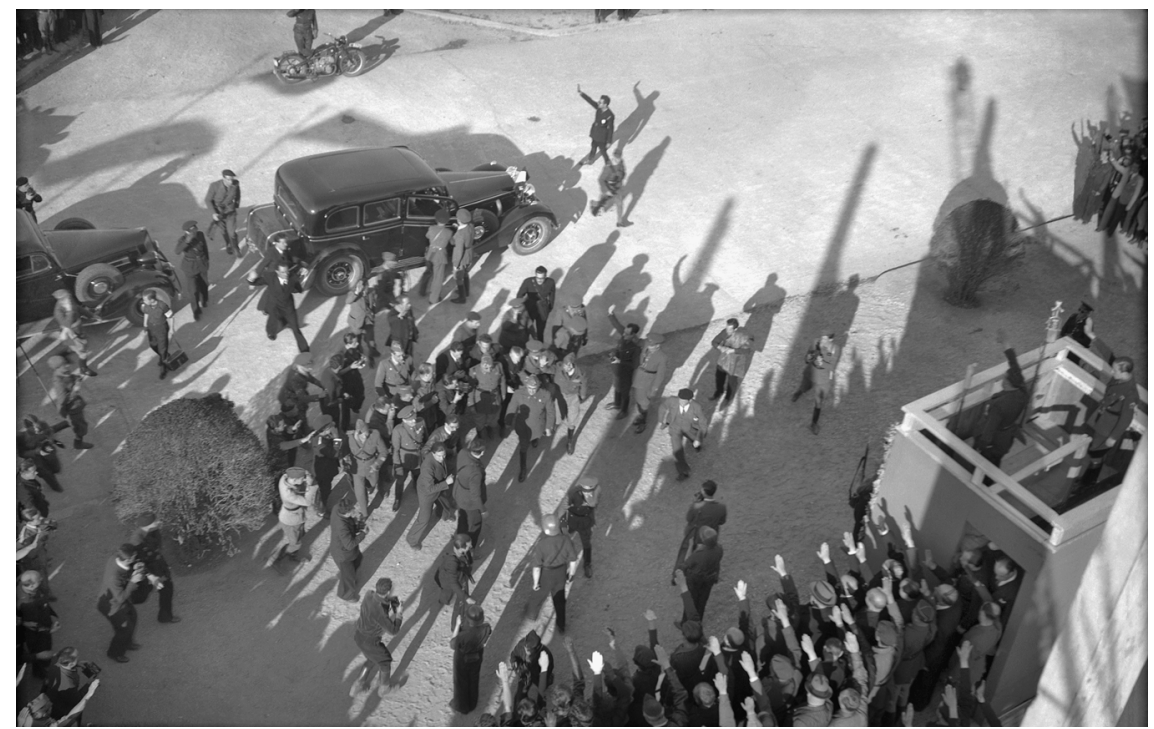

FIGURE 6 Franco arrives at Victory field, Zaragoza, 19 April 1938. SOURCE: FOTOTECA DE HUESCA, SKOGLER ARCHIVE, NO. 2250. 


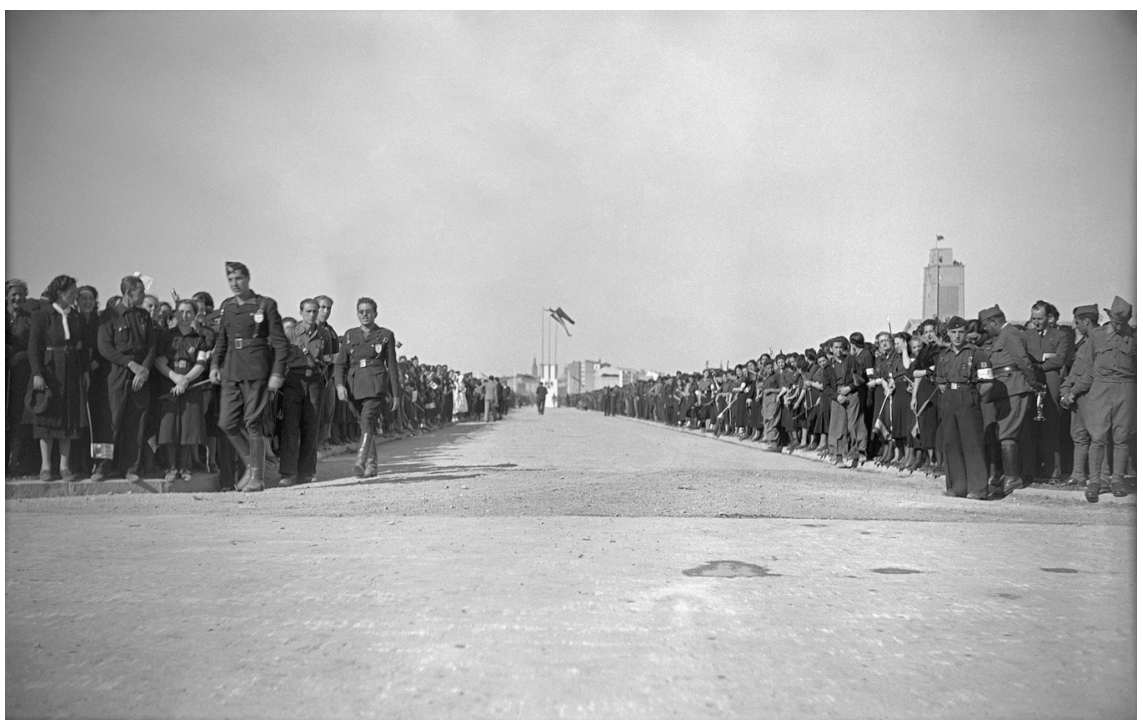

FIGURE 7 Fascist parade and spectacle at Victory field, Zaragoza, 19 April 1938. SOURCE: FOTOTECA DE HUESCA, SKOGLER ARCHIVE, NO. 2098.

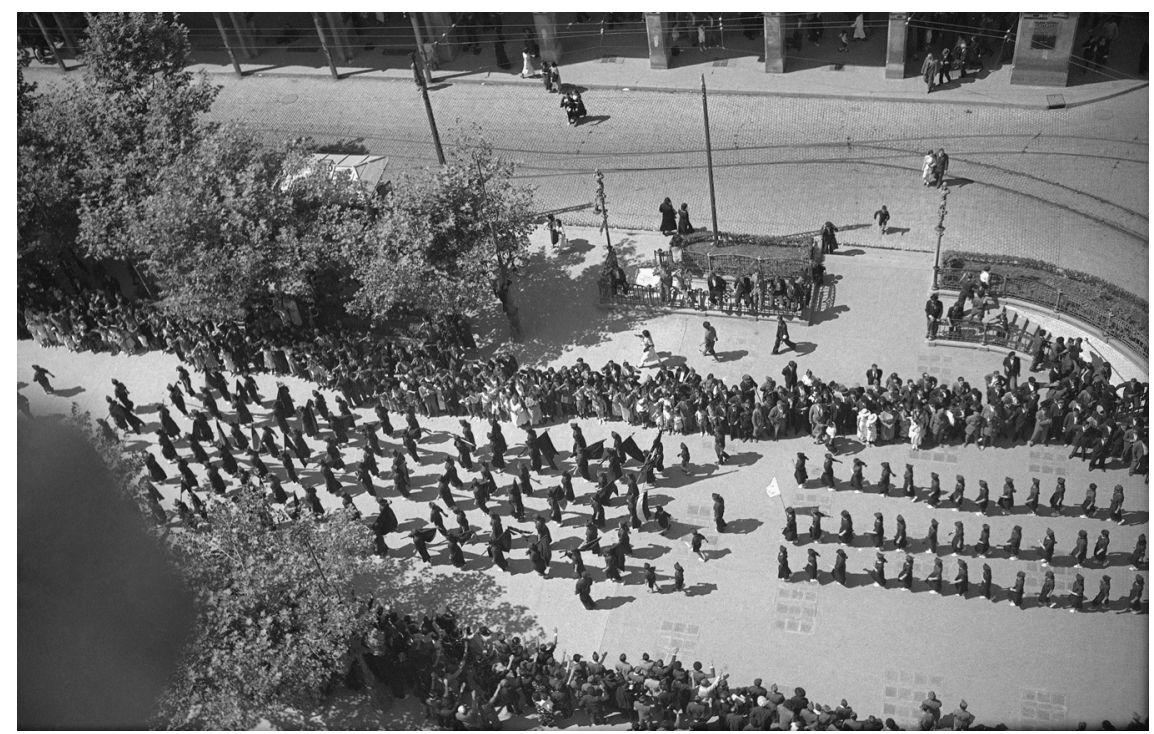

FIGURE 8 'Demonstration by our comrades in Zaragoza on Avenida de la Independencia,' as published in Amanecer, 23 September 1936.

SOURCE: FOTOTECA DE HUESCA, SKOGLER ARCHIVE, NO. 1832. 
part of a spectacle in which the principal photographic intention is to capture the entrenched nature of the Falange's presence and its dominance of the urban space in the Aragonese capital. Skogler's photography is unambiguous, designed to show clear victory and an overwhelming Falangist presence, the exaltation of values and continuous intervention by its cadres and members, from the rank and file members of the Sección Femenina to the most eminent leaders. All of them are portrayed gathered together in the context of whatever official visit was taking place in honour of dozens of official (military, religious, civilian) events organised with all the pomp and circumstance of the fascist mise-en-scène.

However, the city is concealing other problems, other nuances and other colours, not just the red and blue propagated day after day on the pages of Amanecer. There is political tension in the ranks of a Falange that is seeing its revolutionary ideals jeopardised; it is also a city of other tensions, muted by censorship, such as those that are arising between the Italian troops and the Requetés (Carlist militias) or Falangists; and it is the scene of crimes that today are strictly punished under the scrutiny of judicial institutions. It is a city subject to the Catholic rule of Marian traditions and to intense repression and elimination of members of left-wing parties, silenced, naturally, by press organs that are striving to present a falsely cheerful city committed to the victory of the rebels. ${ }^{35}$ In short: it is a city pacified by force, where military actions are only ever characterised as resounding, unparalleled or indisputable successes in the habitual propagandistic prose and visual coverage.

\section{Zaragoza, Rearguard City: Unpublished Images of the Uprising From Inside the Falange}

One of the most dramatic events of the earliest moments of the so-called uprising on the peninsula was the loss of the city of Zaragoza for the Republican cause. ${ }^{36}$ Considered a purely leftist stronghold and, after Barcelona, the bastion of anarchism, the Aragonese capital fell to the insurgents sometime around the morning/afternoon of 23 July 1936 . The forces of the left put up hardly any resistance, having fallen victim to a faith in the rule of law and the expectation of receiving weapons that never arrived, which, ultimately, doomed them. ${ }^{37}$

35 Ángel Alcalde Fernández, Lazos de sangre, 149.

36 Julián Casanova, Anarquismo y revolución en la sociedad rural aragonesa, 1936-1938 (Madrid: Siglo XXI, 1985).

37 Diego Navarro, Morir matando (Seville: Renacimiento, 2012). 
From that point on, the reconquest of Zaragoza would be one of the objectives continuously and fruitlessly pursued by the forces of the left, essentially anarchists, who very soon, in August of 1936, made their way from Barcelona to the Aragonese capital in the Durruti Column, to no avail.38

The Civil War, having scarcely begun, Zaragoza became perhaps the most important defeated city of all of those held by the rebels from early on in the war. There were neither reports of urban fighting nor was it subjected to assault or systematic or significant bombing. Situated geographically at a decisive crossroads in the overall geography of the war fronts, its fate during the conflict was that of a powerful bastion of national trade unionism where Falangist, traditionalist and international forces-with the notable presence of a detachment of the Condor Legion and of the Italian 'Flechas Negras' ['Black Arrows'] —encapsulated the entire universe of the rebel forces. ${ }^{39}$ The ecclesiastical institutions had a decisive role and very active presence, driven by Marian, Pillarist traditions with deep, officially sanctioned roots.

The first moments of the military uprising in Zaragoza find the principal members of the Falange at the Torres Military Training Academy, on Bruil Street, from which they moved their headquarters to the Cavalry Castillejos barracks, in the Torrero neighbourhood. This compound, the headquarters of the cavalry regiment and under the command of Colonel Monasterio (later General), would provide the Zaragozan Falangists with a haven, which, from that point on, they would transform into an operational base. It was from here that they set out on expeditions for punitive purposes, to the front, or to the countless celebrations and parades in the city. Skogler's photographic activity provides numerous details that contribute decisively to outlining quite a few chapters of a city that, since July of 1936 , had become a myth in the Republican, especially the anarchist, imagination due to the dream of retaking it.

\section{July 1936: Unpublished Visions of Falangist Participation from the Castillejos/Torrero Barracks}

With the official founding of Amanecer still over a month away, Skogler went to work as the photographer of that milieu, portraying a Zaragoza clearly taken over by civilian and military forces sympathetic to the military coup. On 18 July itself, 'at the agreed time, young men start to stream into the Castillejos barracks, animating the patios with their joyful and enthusiastic shouts. The

\footnotetext{
38 A complete analysis of that situation with answers about the rapid conquest of Zaragoza by the rebels in Julia Cifuentes Chueca and Pilar Maluenda Pons, El asalto a la República: Los orígenes del franquismo en Zaragoza (Zaragoza: Institución Fernando el Católico, 1995), 17. 
Falangists are anxious about the fate of their comrades incarcerated in the Alcañiz (Teruel) prison, which include territorial chief Jesús Muro, a Zaragozan doctor who was taken to that prison with all the other leaders'. ${ }^{40}$ Nonetheless, around 20 July, with any hope of defence of the Republican constitutional order extinguished, the participation of Skogler and his Falangist comrades in the early days of the uprising are impeccably recorded in a set of negatives with enormous historical significance. They are unpublished images of that hot summer of repression and totalitarian fervour set in motion from the tragically notorious Castillejos barracks referred to several times in these pages.

While the Skogler Archive does not essentially capture scenes of street fighting with the visual impact achieved by Centelles and Capa in Madrid and Barcelona, let alone summary executions in a dynamic of systematised repression, it is easy to localise his presence and that of his Falangist comrades in this first explosion of violence in the summer of 1936. The unsettling photos of the trucks of armed Falangists entering and exiting the temporary central headquarters inside the Torrero barracks, the requisitioned trucks and the eager faces of the comrades give us a sense of latent and dramatically impending violence. Those vehicles that travel from one part of the city to another are the reflection of the relentless contribution of Falangists and members supportive of the 'summer orgy' of violence and repression in Zaragoza and other towns in the province, achieving, no doubt, the imposition of 'an atmosphere of terror and exclusion through which to paralyse opponents and pave the way for the establishment of the regime of the insurgents.' ${ }^{41}$ They would be beehives from which the daily repression would embark, like the Castillejos barracks, unmistakable spaces within the urban geography of Falangist violence that contrasted with the fundamental objective of the press at that moment: to deny the facts, impose absolute calm, downplay any type of difficulty in a city controlled and under the parameters of tranquillity, order and resumption of normal life in spite of the vicissitudes of those uncertain days between July 18 and 23. The magnitude of the repression unleashed in the city by the rebels in the months of July, August and September of 1936 was enormous and did not subside afterwards. Early first-hand accounts by direct witnesses, like the horrific diary penned by Father Estella (chaplain of the Torrero prison) or lists

$40 \quad$ Historia de la Cruzada Española, vol. 4, no. 14, 203.

41 José Luis Ledesma, 'Se rompió el tiempo: Fragores de ruina y muerte en el Aragón en guerra,' in Paisajes para después de una guerra 1936-1957: El Aragón devastado y la reconstrucción bajo el Franquismo, ed. Carlos Forcadell and Alberto Sabio Alcutén (Zaragoza: IFC, 2008), 31. 
of people shot inside its walls, are indicators of the tragedy in which the forces of the Falange played a direct role as action groups. ${ }^{42}$

The image projected of official normality in the photos taken for Amanecer falls apart when images taken from within the Falange, by one of its own, tell us of incessant activity by squads, squadrons and uniformed soldiers with attitudes that were anything but timid or half-hearted. Today's San Fernando barracks of Zaragoza, at the entrance to the Torrero neighbourhood, occupies the grounds of the barracks where the Falangists were concentrated. In fact, more than any other unit attached to the Fifth Organic Division, the barracks of the First Cavalry Regiment, Castillejos, was the most committed and determined of all in the first moments of the uprising. ${ }^{43}$ They were led by Colonel Monasterio, with Lieutenant Colonel Urrutia as second-in-command and military chief of falangist militias, two co-conspirators against the Republic and fervent champions of the uprising. ${ }^{44}$

Skogler went to the Castillejos barracks as a veteran Falangist. In the photographic archive analysed here, there is a very interesting group of negatives that reflect the frenetic activity inside and outside the Torrero barracks in those July days. The trucks and requisitioned automobiles, the visits of military men, the haranguing of the comrades, the preparations for retaliatory expeditions are all recorded by Skogler himself as a Falangist and as a photographer, once more highlighting the decisive role the barracks played in the victory of the military uprising:

As we have already mentioned, the role of these Falangist volunteers was to act as action troops for the uprising, in addition to serving as an ideological stimulus within the military units to which they were distributed. They were established in the Castillejos barracks, the base for setting out on their expeditions. According to El Noticiero, these expeditions consisted not just of war actions but also actions aimed at occupying the provincial

42 Gumersindo de Estella, Fusilados en Zaragoza: 1936-1939, tres años de asistencia espiritual a los reos (Zaragoza: Mira, 2014).

43 Julia Cifuentes Chueca and Pilar Maluenda Pons, El asalto a la República: Los orígenes del franquismo en Zaragoza (Zaragoza: Institución Fernando el Católico, 1995), 19. 'It is an established fact that the most active nucleus of the uprising came not from the Captaincy but from other military centers, mainly the "Castillejos" calvary barracks'.

44 Historia de la Cruzada Española, vol. 4, no. 14, 196. "The root of the uprising in the Aragonese capital is in the Castillejos Barracks. The Regiment-which occupies the area around the military church of San Fernando, the Torrero buildings ....-is commanded by Colonel José Monasterio, a man of few words but definite and firm in his intentions. ... Second in command is Lieutenant Colonel Gustavo Urrutia, impetuous, resolute, closely aligned with Colonel Monasterio, and his first and most reliable collaborator'. 
towns to which they were gradually extending the uprising, guarding town halls, going out on patrols, escorting convoys, frisking people and conducting searches in red districts, vehemently eradicating dangerous hidden groups of Marxists, etc. ${ }^{45}$

These selected photographic negatives have no date markings, simply a brief notation: 'first march'. Nonetheless, the architecture studio corresponds to a zone near the Castillejos barracks of Zaragoza. Cross-checking against indirect information about these Falangist images taken next to the Castillejos barracks enables us to guess the approximate date of July 1936. More specifically, the presence of the chief of the Falange of La Mancha, José Sáinz Nothnagel, in these barracks makes it possible to narrow down this date even further. ${ }^{46}$

The presence of Sáinz Nothnagel in Zaragoza is easy to explain. He had been imprisoned in Alcañiz, along with Muro Sevilla and other high-ranking Falangists, by the Republican authorities as the fascist ringleaders of an imminent uprising on the $5^{\text {th}}$; thanks to the decisive intervention of Urrutia and Monasterio, and under the orders issued by Cabanellas early on the morning of the 19th, they were liberated from the Alcañiz prison. ${ }^{47}$ In reference to those hours, Muro himself stated the following:

At two in the afternoon, we clearly heard the words 'Arriba España!' followed by several gunshots. For a few instants we were stunned. Then we feverishly shed the jumpsuits we had been wearing during our time in the prison and got dressed while waiting for something to happen and thinking that the die was cast. After quite a few attempts, I managed to get in touch with the lieutenant of the Civil Guard, who informed me that two Falange squads from Zaragoza had arrived and, together with the Falangists of Alcañiz, had taken over the town. Imagine our joy .... Once the town was normalised, I assembled all the Falange elements, precisely ninety-eight, and we immediately left for Zaragoza in two buses and four or six cars. On the road, we encountered two companies of cavalry soldiers and one Falange company with three machine guns who were on their way to rescue us, suspecting that something had befallen us when we still hadn't reached Zaragoza by five o'clock on the 19th. We took leave of them and continued on our way. ${ }^{48}$

\footnotetext{
45 Ángel Alcalde Fernández, Lazos de sangre, 49. Quoting from El Noticiero, 25 Julio 1936.

46 Ibid., $42-43$.

47 José María Maldonado, Alcañiz 1938: El bombardeo olvidado (Zaragoza: Ibercaja, 2003), 27-29.

48 Historia de la Cruzada Española, vol. 4, no. 14, 213.
} 

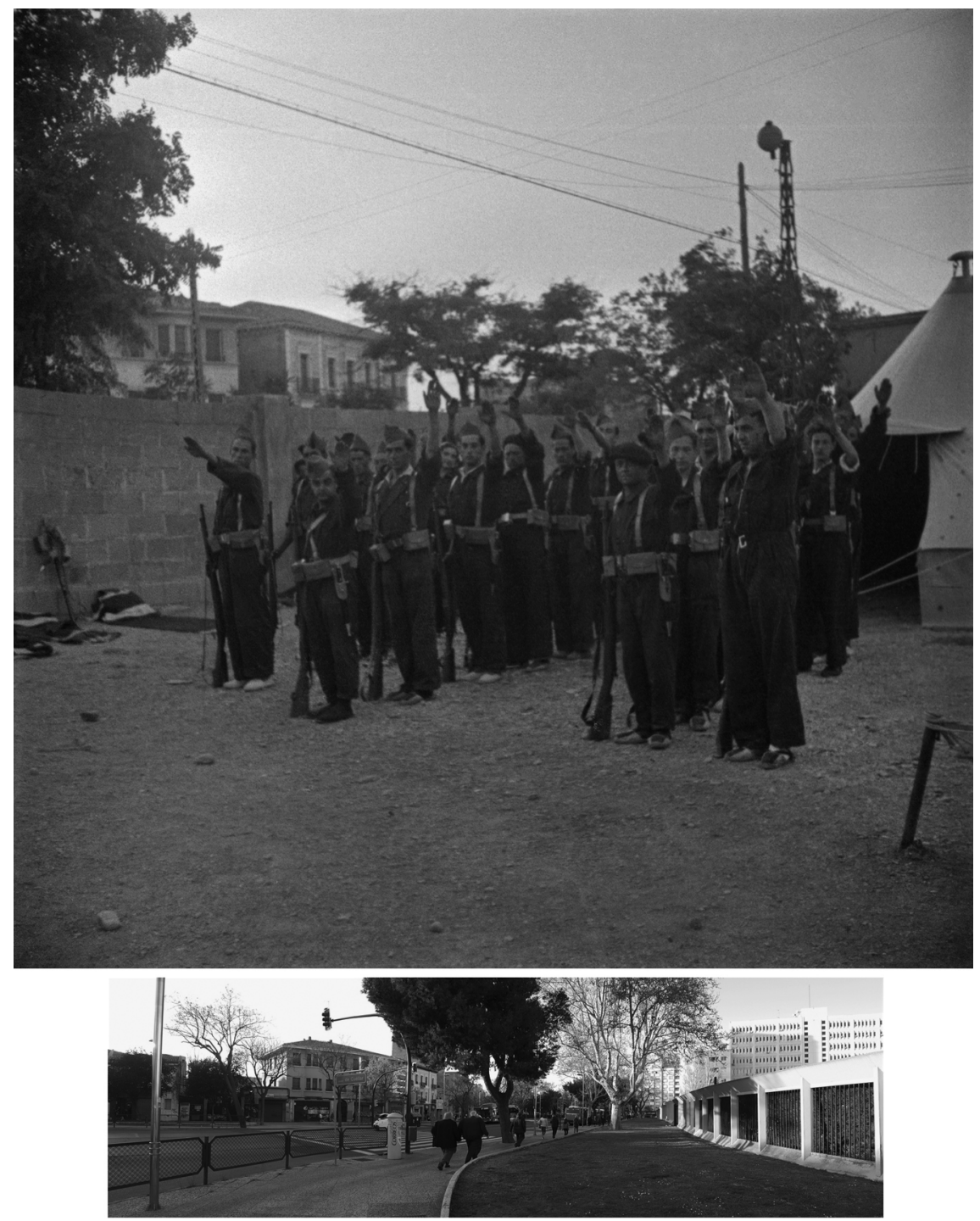

FIGURE 9 Falangist forces perform the fascist salute inside the Castillejos barracks of Zaragoza, circa 20 July 1936. Today, the zone is occupied by the San Fernando Barracks.

SOURCE: FototeCA DE HUESCA, SKogler ARCHIVE, NO. 272. 


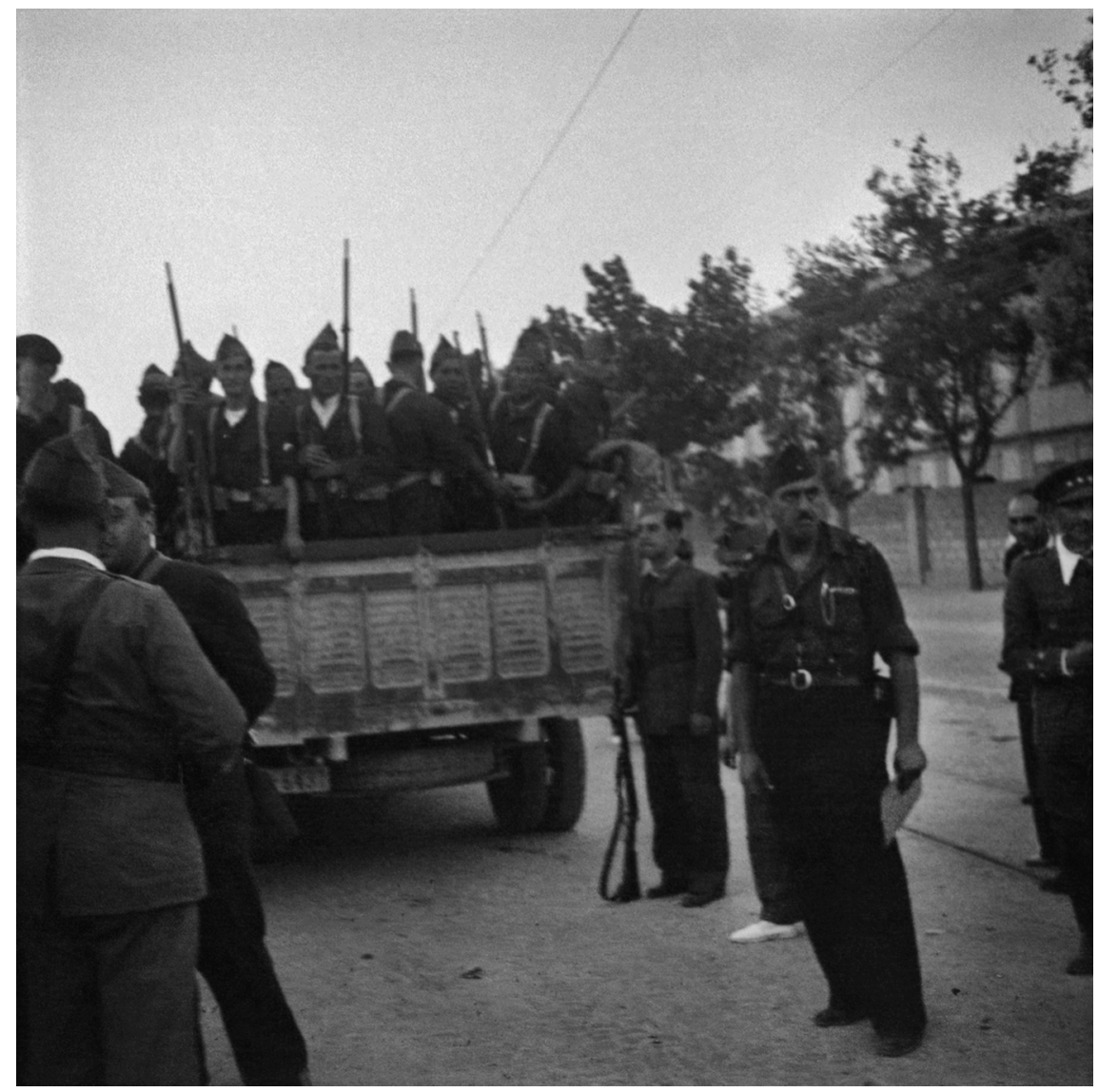

FIGURE 10 Jesús Muro Sevilla, the Falange chief, in connivance with the soldiers of the Torrero cavalry barracks, issues instructions and organises a departure of Falangists in trucks from the barracks compound. Zaragoza, [19-24 July] 1936.

SOURCE: FOTOTECA DE HUESCA, SKOGLER ARCHIVE, NO. 287.

The eventful biography of Sainz Nothnagel places him in Logroño on July 25 th. ${ }^{49}$ Therefore, the photos taken by Skogler in which Sainz appears, and of those first moments of the uprising in Zaragoza, can only be from the return of the two men from the Alcañiz prison: sometime between Sunday afternoon on

49 Carlos Vega, 'Fotografía histórica de la Guerra Civil,' Toledo GCE Blog, 3 February 2016, https://toledogce.blogspot.com/2016/o2/el-jefe-provincial-de-falange-jose.html, accessed 28 February 2019. 


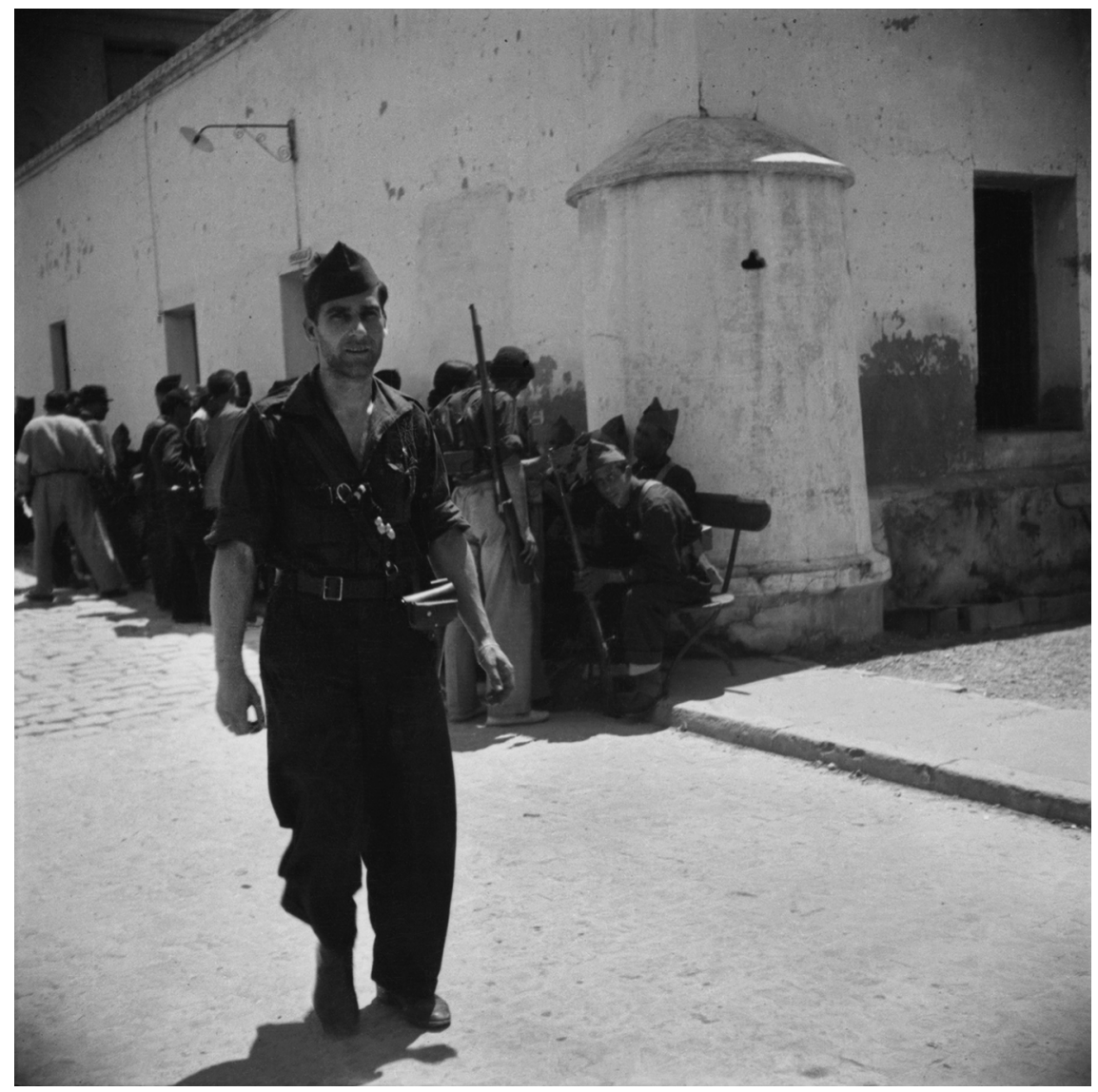

FIGURE 11 José Sáinz Nothnagel, Falangist regional chief of La Mancha, is photographed by Ángel Cortés Alcañiz following his arrival from the Alcañiz prison. [19-24 July], 1936.

SOURCE: FOTOTECA DE HUESCA, SKOGLER ARCHIVE, NO. 313

19 July 1936 and the 24th, the day Sainz Nothnagel leaves Zaragoza to assume the leadership of the Falangist militias in La Rioja. ${ }^{50}$

That same July 23rd, the news media sympathetic to the rebels breaks down the chronology of the photos taken by Skogler and offers what is

50 El Noticiero, 25 July 1936, 3: 'Both chiefs were detained in Alcañiz with some other elements while traveling through Lower Aragon en route to prepare for the current movement and organisation of the militias ... At four-thirty, after the corresponding formalities, they were freed. At six o'clock, both chiefs were on their way to Zaragoza to dedicate themselves to organising the very large contingent of volunteers who wanted to fight under the sign of the yoke and arrows'. 


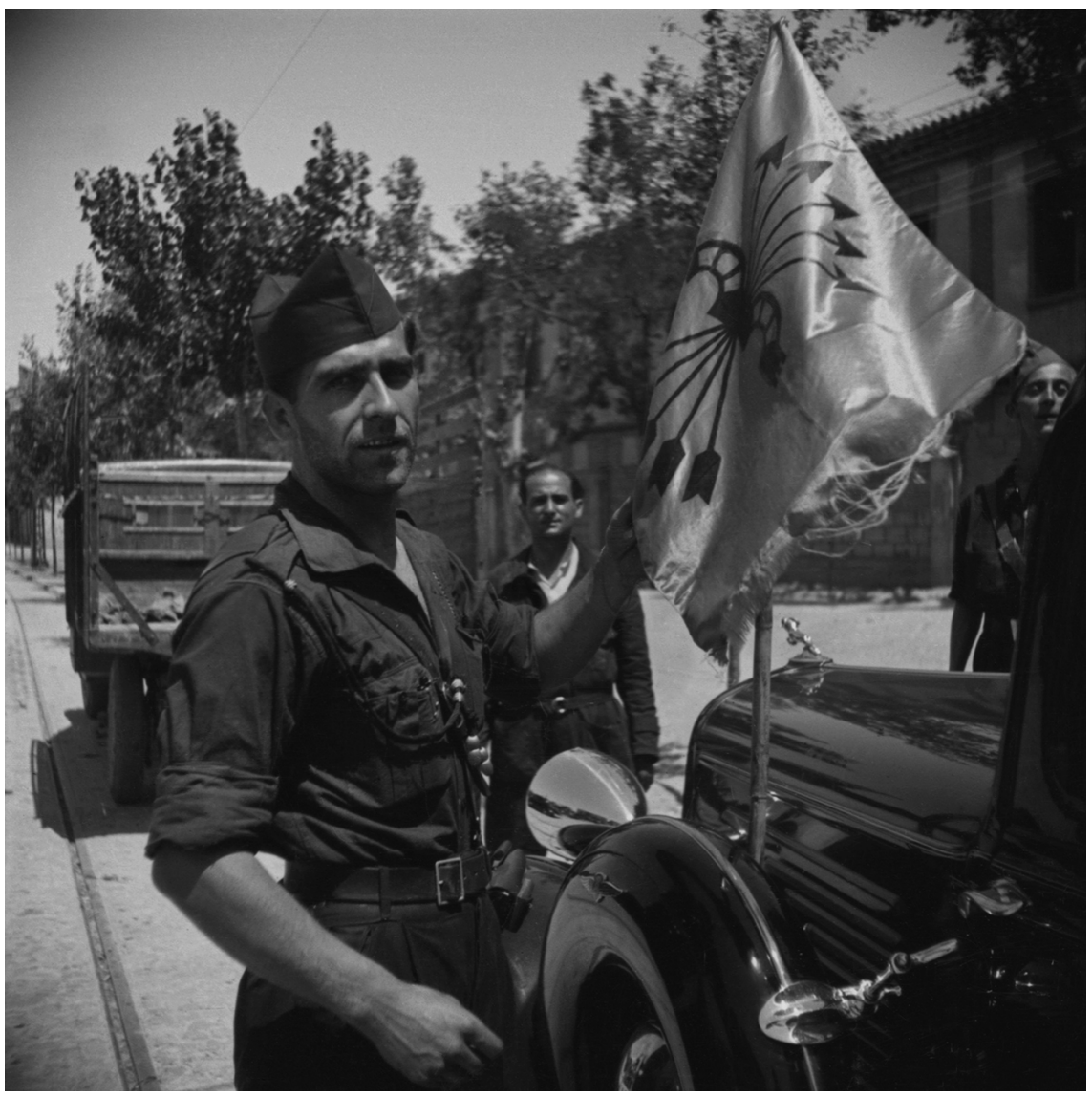

FIGURE 12 Under the emblem of the yoke and arrows. José Sáinz Nothnagel next to a Falange automobile, at the gates of the Castillejos barracks. Zaragoza, [19-24 July], 1936. SOURCE: FOTOTECA DE HUESCA, SKOGLER ARCHIVE, NO. 67.

almost certainly an accurate description of the unpublished images we are analysing here.

The Castillejos infantry [sic] barracks at the same time serve as the headquarters of the deployed Falangist troops. Hundreds of men, almost all dressed in the blue jumpsuit that had been adopted as a combat uniform, rest, do guard duty, assemble in formation, sing songs, receive training, wander about. The national trade union movement is a powerful reality. Vans and cars enter and exit with patrols and crews that are renewed constantly. Nonetheless, the orderliness is admirable. Every crew is dealt with meticulously, every order rigorously executed, every detail shows an iron discipline at the service of their deeply felt exalted ideal. The 


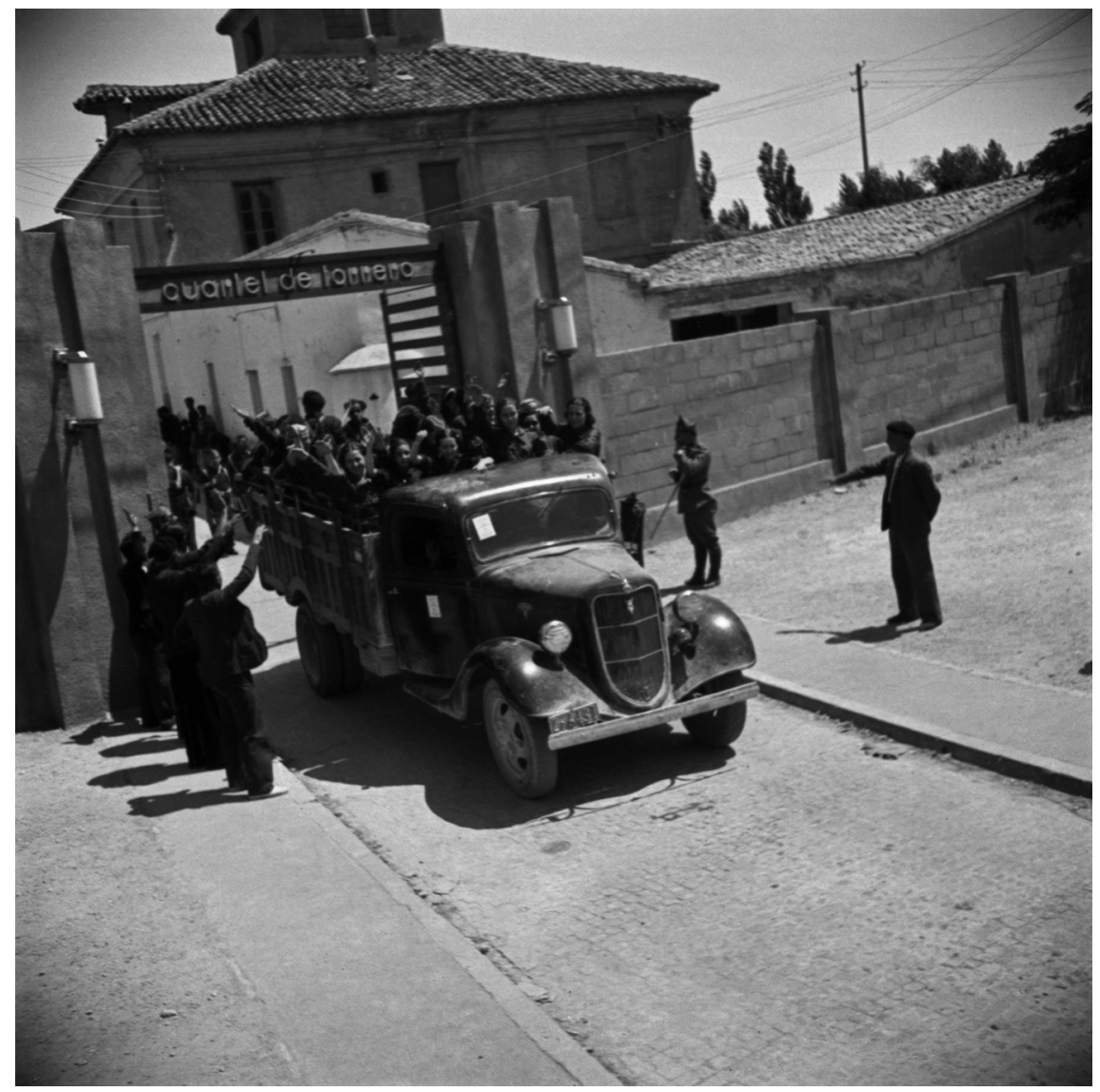

FIGURE 13 Trucks carrying groups of Falangists with raised arms departing from the Castillejos barracks, in Torrero, [19-24 July], 1936.

SOURCE: FOTOTECA DE HUESCA, SKOGLER ARCHIVE, NO. 65 AND 289-290.

barracks house Falangists, 2,500 in number, who are doing their service in Zaragoza. In two patios there are 14 tents in which the deployed men sleep atop piles of straw and covered by a blanket. But comforts are superfluous when the spirit is inclined towards sacrifice. The centurias and Falangist troops are commanded by civilians who hold the leadership positions in the national trade union militias. However, at the moment, to achieve greater effectiveness in the deployments, the commands have been taken over by soldiers already active in the ranks of the Spanish Falange. At their side, sharing command, is the civilian officer formally in charge of the militias .... It is striking to see them marching with the circumstantial irregularity of their uniforms. According to the rules, the 


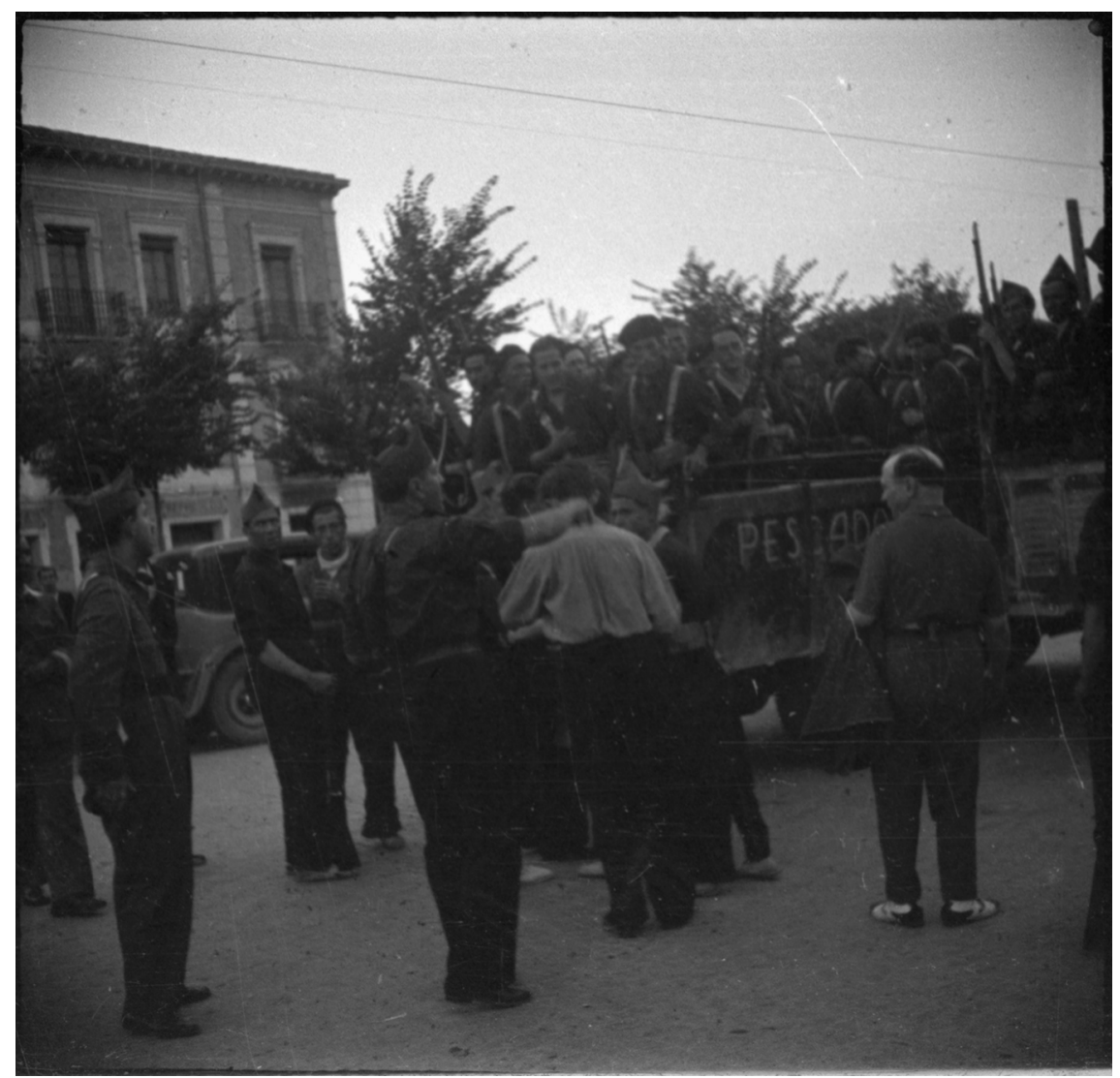

FIGURE 14 Jesús Muro Sevilla, the Falange chief, in connivance with the soldiers of the Torrero cavalry barracks, issues instructions and organises a departure of Falangists in trucks from the barracks compound. [19-24 July] 1936.

SOURCE: FOTOTECA DE HUESCA, SKOGLER ARCHIVE, NO. 287.

uniform of the Falangists is a blue shirt with the yoke and arrows embroidered in red on the left pocket, and long black pants without cuffs. But the conditions of this improvised movement have made it impossible to supply all the deployed men with uniforms. And, so we see that—as in all wars-each man does ... the best he can. ${ }^{51}$

$5^{1} \quad$ El Noticiero, 23 July 1936. 


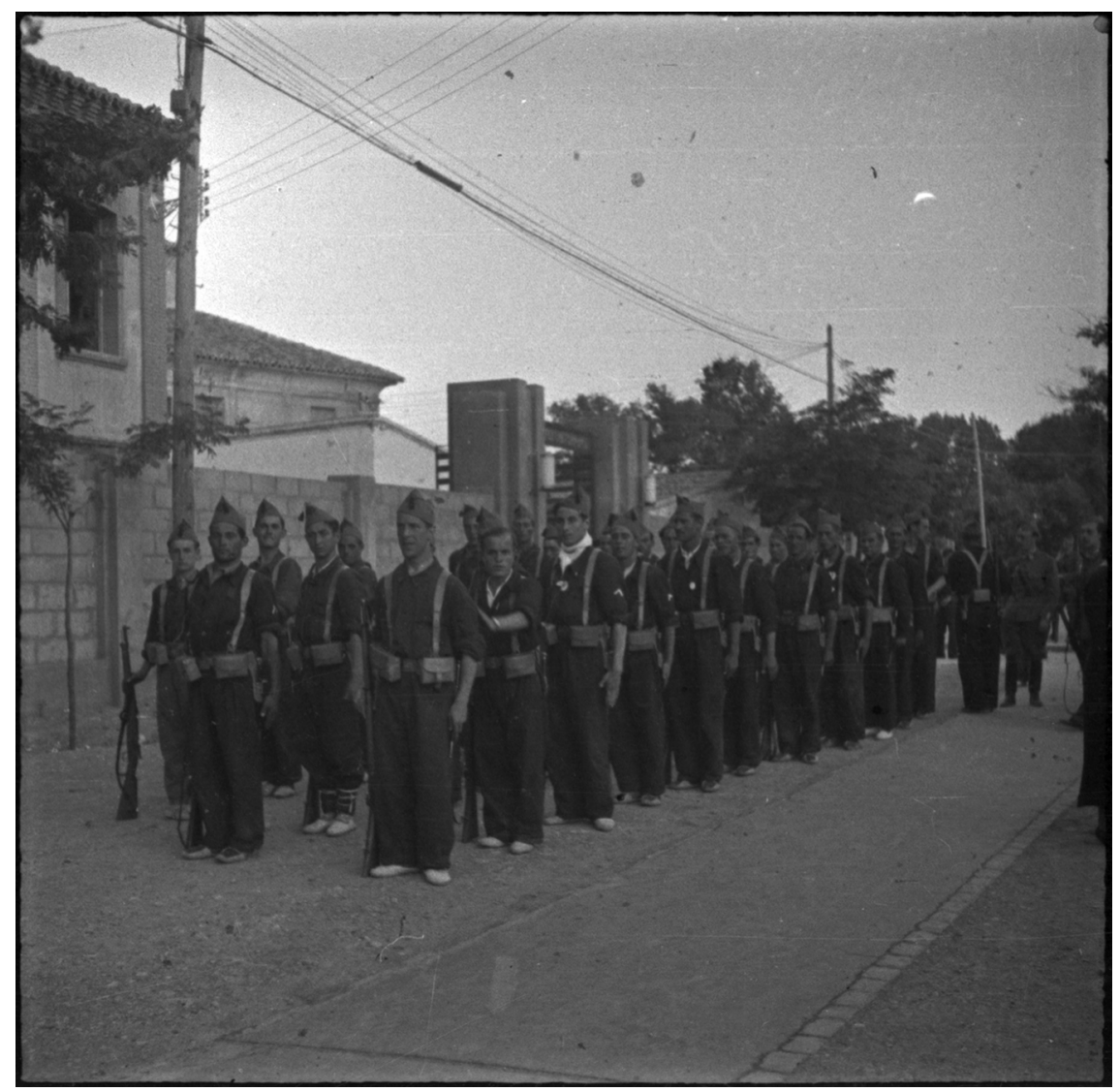

FIGURE 15-17 Column of Falangists in formation at the gates of the Castillejos barracks in Torrero. [19-24 July], 1936.52

SOURCE: FOTOTECA DE HUESCA, SKOGLER ARCHIVE, NO. 277, 279, 281.

52 The events and participants of these early days were commented in Historia de la Cruzada Española, Madrid, Ediciones Españolas, vol. 4, no. 14 (1941), 213. 


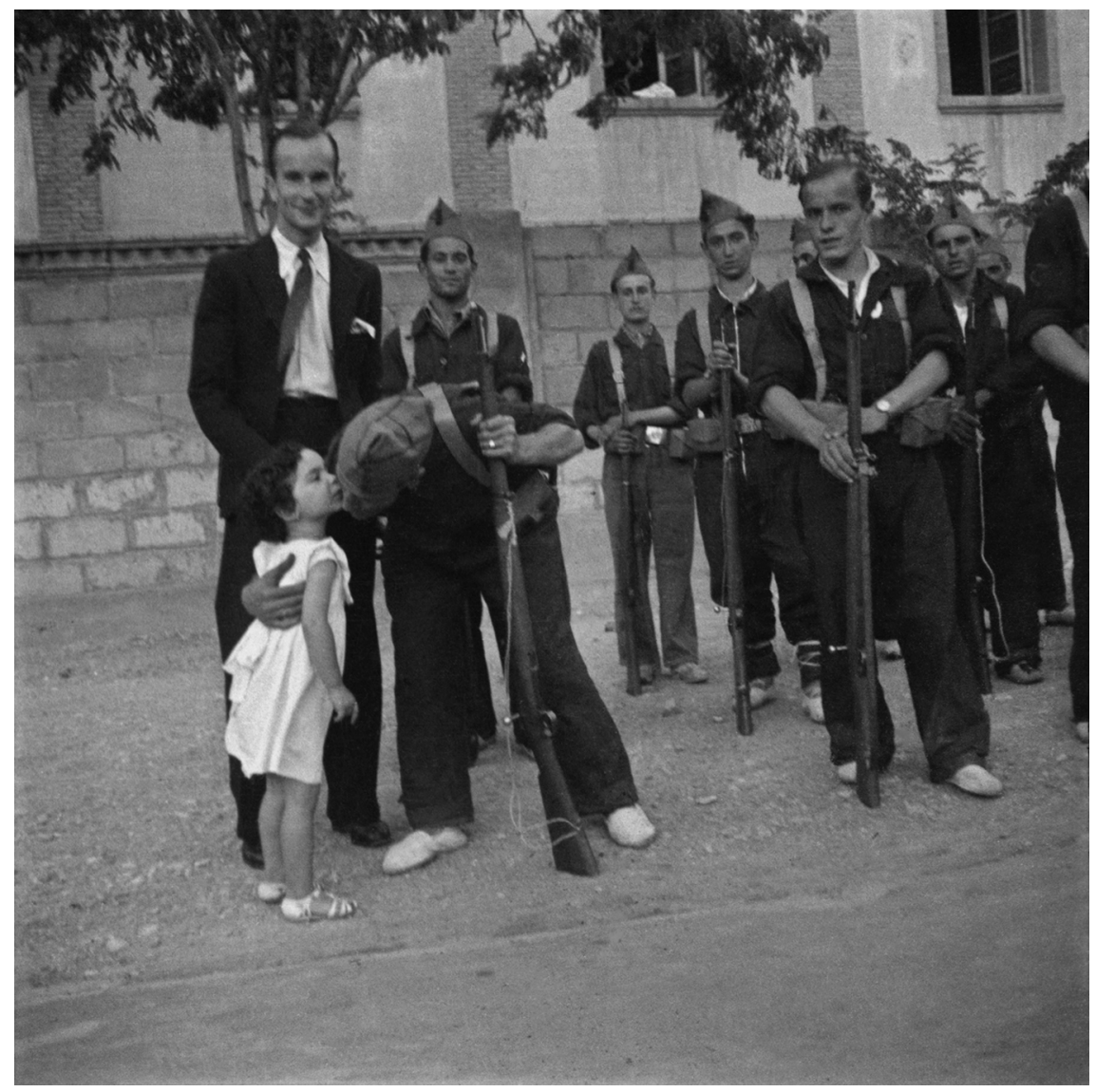

FIGURE 15-17 Continued. 


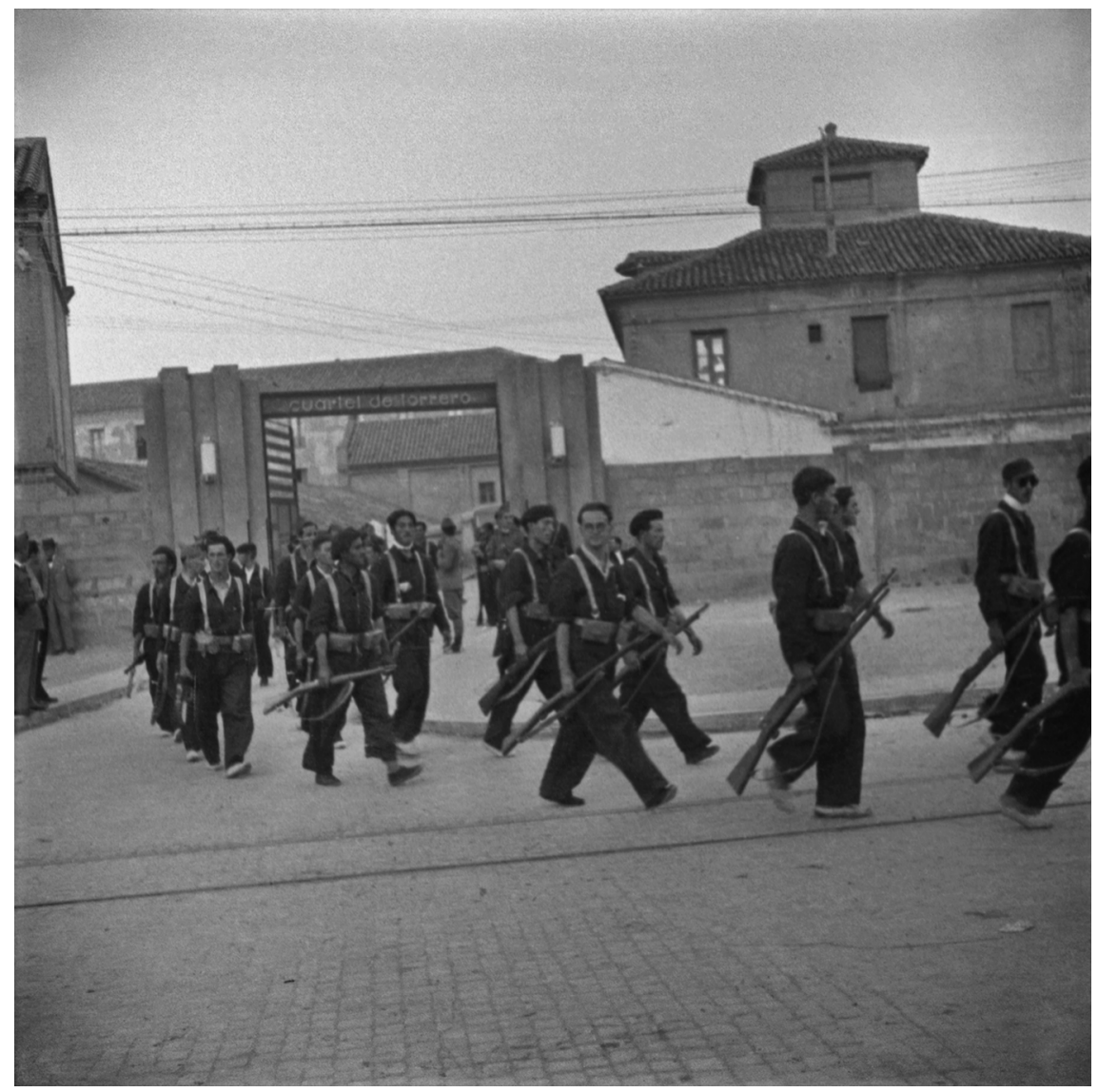

FIGURE 15-17 Continued.

\section{Conclusion}

The visual narrative supplied by the fascist photography of the Spanish Civil War incorporates a practically unknown archive of over 3,500 items. The photographer Ángel Cortés Gracia pursued his professional activity under the name 'Fotografía Skogler'. In the 1930s, his early militancy in the Falange Española and, therefore, his status as a Camisa Vieja situated him in an advantageous position to observe the political, military and social activity of the Zaragoza that fell into rebel hands in July 1936. His active fascist militancy allowed him to join the photojournalism team of the newspaper Amanecer starting in August 1936. He covered practically every official function of the Spanish Falange in Zaragoza, photographed the battlefronts, was wounded in Madrid, accompanied the delegation that helped transport the casket carrying the remains of 
José Antonio Primo de Rivera from Alicante in 1939 and, in short, participated extremely actively in support of the Falangist vision in the Aragonese capital, always on the side of the Falange's territorial chief, Jesús Muro Sevilla.

His participation in the military coup against the Republic makes him unique as a photographer for having taken hitherto unknown photos inside the Castillejos Cavalry barracks itself, where the fascists troops were deployed in the city of Zaragoza. Taken barely two days after the military uprising, they constitute a prime historical source for enhancing our knowledge of the role played by the Falange in the armed take-over of the city by contributing to enriching the manifold (and confusing from a historiographic standpoint) Falangist photographic history of the beginning of the Spanish Civil War. As an individual firmly committed to the fascist movement in one of the cities that clearly fell under the domination of the rebel nationalist forces he supported a sort of pure Falangist ideology, he did not fit in with the new guidelines from the General Secretariat of the Movement that were to shape the ideology of the postwar Falange. Just after covering the Victory parade, he would be progressively denied assignments for Amanecer, ultimately returning to his photography studio in the city of Zaragoza. Fortunately, his photographic archive remains intact, giving us an understanding of the strong presence of the Falangist movement in the streets of cities and small towns.

\section{Acknowledgements}

This article is a contribution to the research project: 'From manuscript to screens: memory, artefacts and cultural practices (15th Century to present)'. Spain, Ministry of Economy, Industry and Competitiveness. Ref: HAR2o167655 oP. Principal investigator: Dr. Enrique Villalba Pérez (UC3M).

We gratefully acknowledge the extremely useful and kind assistance of the Fototeca de Huesca, Archive-Library of the City Hall of Zaragoza, Administration General Archive's director, Mercedes Martín-Palomino, Francisco Boisset and Esthela Ibáñez, Luis Serrano, Víctor Francisco Fernández-Zarza and, in particular, the Bericat-Cortés family for their generous indications and kindness over the course of the research project. 